\title{
Comparative Proteomic Analysis Reveals Elevated Capacity for Photosynthesis in Polyphenol Oxidase Expression-Silenced Clematis terniflora DC. Leaves
}

\author{
Xi Chen ${ }^{1,+} \oplus$, Bingxian Yang ${ }^{1,+} \oplus$, Wei Huang ${ }^{1}$, Tantan Wang ${ }^{1}$, Yaohan Li $^{1}$, Zhuoheng Zhong ${ }^{1}$, \\ Lin Yang ${ }^{2}$, Shouxin $\mathrm{Li}^{3}$ and Jingkui Tian ${ }^{1,4, *}$ \\ 1 College of Biomedical Engineering \& Instrument Science, Zhejiang University, Zheda Road 38, \\ Hangzhou 310027, China; 21615052@zju.edu.cn (X.C.); xianyb@zju.edu.cn (B.Y.); \\ 21615051@zju.edu.cn (W.H.); 21615085@zju.edu.cn (T.W.); 21815031@zju.edu.cn (Y.L.); \\ zhongzhh@zju.edu.cn (Z.Z.) \\ 2 Zhuhai Weilan Pharmaceutical Co., Ltd., Zhuhai 519030, China; LinYangzhuhai@163.com \\ 3 Changshu Qiushi Technology Co., Ltd., Suzhou 215500, China; 0016837@zju.edu.cn \\ 4 Zhejiang-Malaysia Joint Research Center for Traditional Medicine, Zhejiang University, \\ Hangzhou 310027, China \\ * Correspondence: tjk@zju.edu.cn; Tel.: +86-571-88273823; Fax: +86-571-87951676 \\ + These authors contributed equally to this work.
}

Received: 21 September 2018; Accepted: 2 December 2018; Published: 5 December 2018

\begin{abstract}
Polyphenol oxidase (PPO) catalyzes the o-hydroxylation of monophenols and oxidation of o-diphenols to quinones. Although the effects of PPO on plant physiology were recently proposed, little has been done to explore the inherent molecular mechanisms. To explore the in vivo physiological functions of PPO, a model with decreased PPO expression and enzymatic activity was constructed on Clematis terniflora DC. using virus-induced gene silencing (VIGS) technology. Proteomics was performed to identify the differentially expressed proteins (DEPs) in the model (VC) and empty vector-carrying plants (VV) untreated or exposed to high levels of UV-B and dark (HUV-B+D). Following integration, it was concluded that the DEPs mainly functioned in photosynthesis, glycolysis, and redox in the PPO silence plants. Mapman analysis showed that the DEPs were mainly involved in light reaction and Calvin cycle in photosynthesis. Further analysis illustrated that the expression level of adenosine triphosphate (ATP) synthase, the content of chlorophyll, and the photosynthesis rate were increased in VC plants compared to VV plants pre- and post HUV-B+D. These results indicate that the silence of PPO elevated the plant photosynthesis by activating the glycolysis process, regulating Calvin cycle and providing ATP for energy metabolism. This study provides a prospective approach for increasing crop yield in agricultural production.
\end{abstract}

Keywords: Clematis terniflora DC.; polyphenol oxidase; virus induced gene silencing; photosynthesis; glycolysis

\section{Introduction}

Polyphenol oxidase (PPO) is an oxidoreductase that catalyzes the oxidation of monophenols and/or o-diphenols to o-quinones, which form brown melanin pigments in fruits and vegetables by covalently modifying and cross-linking proteins [1,2]. However, PPO is not only involved in the formation of pigments, but also plays a crucial role in the biosynthesis of secondary metabolites such as aurones [3] and betalins [4]. PPO solitarily catalyzes the hydroxylation and oxidative cyclization of chalcones, leading to the formation of aurone [3]. In addition, PPO, a tyrosinase can also hydroxylate tyramine into dopamine, which in the presence of betalamic acid yields dopamine-betaxanthin that 
can be further oxidized to yield 2-des-carboxy-betanidin [4]. Furthermore, PPO also has roles in plant defense against insects and pathogens. In transgenic tomato plants, PPO overexpression greatly increases resistance to Pseudomonas syringae [5], and the manipulation of PPO activity provides simultaneous resistance to both disease and insect pests [6]. A recent study on strawberries illustrated that PPO overexpression delays the fungal infection [7]. PPOs may perform different functions in diverse plant species and possibly have multiple roles in plants for the huge PPO gene families.

Potential roles for PPO in plants have also been suggested for adaption to abiotic stresses. A study in olive trees showed oxidation of phenolic is inhibited by decreased PPO, suggesting there is an association between decreased PPO activity and improved antioxidant capacity [8]. The role of PPO in regulation of cell death in walnuts was explored, where silencing of PPO resulted in increased tyramine, which elicited cell death in walnuts [9]. Furthermore, a recent study also demonstrated the potential of PPO in bioremediation and food/drug industries as it significantly reduces the phenol content in an artificial solution [10]. As well as evidence supporting that PPOs play a role in plant defense against biotic stressors, several independent lines of evidence identified PPO with a chloroplastic location, linking PPO with photosynthesis. However, although an interaction between photosynthesis and PPO activity has been presented more than once [11-13], evidence either for or against direct involvement has been ambiguous, and the absence of chloroplastic substrates that were identified remains an issue.

Virus-induced gene silencing (VIGS) takes advantage of plant RNAi-mediated antiviral defense and has been used widely in plants to analyze gene function [14]. Lee et al. [15] used VIGS to analyze the susceptibility and resistance functional wheat genes involved in Zymoseptoria tritici. Using the barley stripe mosaic virus-VIGS technique, Zhao et al. [16] indicated that the TNBL1 gene is an important gene positively involved in wheat defense response to barley yellow dwarf virus infection. Groszyk et al. [17] analyzed the Bx1 gene ortholog in rye using VIGS and found it to be functionally involved in benzoxazinoid biosynthesis. Recently, VIGS has been a powerful alternative technology for determining the unknown functions of genes and a combination of VIGS and omics is evolving as a competitive strategy for gene function analysis. VIGS and proteomic analysis of the resistance of cotton to Veticillium dahia revealed that gossypol, brassinosteroids, and jasmonic acid contribute to this process [18]. The role of the tomato TAGL1 gene in regulating the accumulation of fruit metabolites was investigated using VIGS and metabolomics analyses [19]. An improved virus-induced gene silencing approach was used to elucidate the role of highly homologous Nicotiana benthamiana ubiquitin enzymes gene family members in plant immunity [20]. In addition, VIGS technology as a powerful investigation tool is still on the way with its application potentials remaining to be fully developed.

Clematis terniflora DC. is a Chinese folk medicinal resource with important pharmaceutical value in the treatment of inflammatory symptoms in the respiratory and urinary systems [21]. Studies have shown that the extracts from the leaves and stems of $C$. terniflora have anti-inflammatory, anti-tumor, and anti-nociceptive effects [22-25]. Furthermore, omics technologies were used on C. terniflora to prospectively understand the inherent mechanism underlying its medicinal quality $[24,26]$. Considering the role PPO played in stress resistance of plant and biosynthesis of secondary metabolites, regulating PPO activity or gene expression can be beneficial to the yields and quality of medicinal plants. Therefore, the potential relationships between photosynthesis and PPO activity are highly relevant to the improvement of yields and quality [27]. To have insight into this relationship, a comparative proteomic analysis was performed on the leaves of $C$. terniflora DC. with down-regulated PPO activity by VIGS in this study. High-intensity UV-B and dark incubation (HUV-B+D), which are helpful stressors for medicinal plants [28], were used for an integration study.

\section{Results}

\subsection{Cloning, Sequence Analysis, and Phylogenetic Tree Analysis of CtPPO}

Following the identification of CtPPO transcript in C. terniflora transcriptome data, $1681 \mathrm{bp}$ of PPO cDNA was cloned from C. terniflora leaves using RT-PCR and 5' RACE with the complementary application 
of genome-walking technologies (Figure S2a). Sequence analysis of CtPPO cDNA revealed a 166-bp $5^{\prime}$-untranslated region (UTR) located upstream of a start codon and an open reading frame (ORF) of 1681 bp encoding 586 amino acids with a calculated molecular mass of $66.11 \mathrm{kDa}$ and an isoelectric point of 7.18.

Blast analysis of the predicted CtPPO amino acid sequence revealed $62 \%$ similarity with Nelumbo nucifera. To further understand the evolutionary relationships between CtPPO and PPO in other plants, a phylogenetic tree was constructed based on amino acid sequence. Phylogenetic analysis showed CtPPO has a close evolutionary relationship with the PPO gene in N. nucifera, but not other plant species (Figure S2b).

\subsection{Virus-Induced Gene Silencing of CtPPO in C. terniflora DC}

VIGS provides an alternative approach for functional analysis of genes. Here, to determine the role of CtPPO, we silenced CtPPO using tobacco rattle virus (TRV)-mediated gene silencing. We constructed two modified TRV vectors: TRV-CtPPO and TRV-PDS. To determine the extent of silencing, we performed qRT-PCR to analysis the transcript levels of the CtPPO gene in inoculated plants. RNA extracted from $C$. terniflora agro-infiltrated with empty vector TRV or TRV-CtPPO or control leaves 20 days post-infection were used for qRT-PCR. As shown in Figure 1a, CtPPO expression levels were reduced in plants infiltrated with TRV-CtPPO compared to the control plants (VIGS-vector and control). To further confirm CtPPO expression, we measured CtPPO activity in control, TRV-vector and TRV-CtPPO plants. In VIGS-CtPPO (VC), PPO activity was significantly lower than in VIGS-vector (VV) and control, illustrating that a successful VC plant model was constructed (Figure 1b). Despite these obvious changes in CtPPO in plants, however, there were no macroscopic phenotypic differences in the VC, VV, and control leaves at the starting point (Figure 1c).

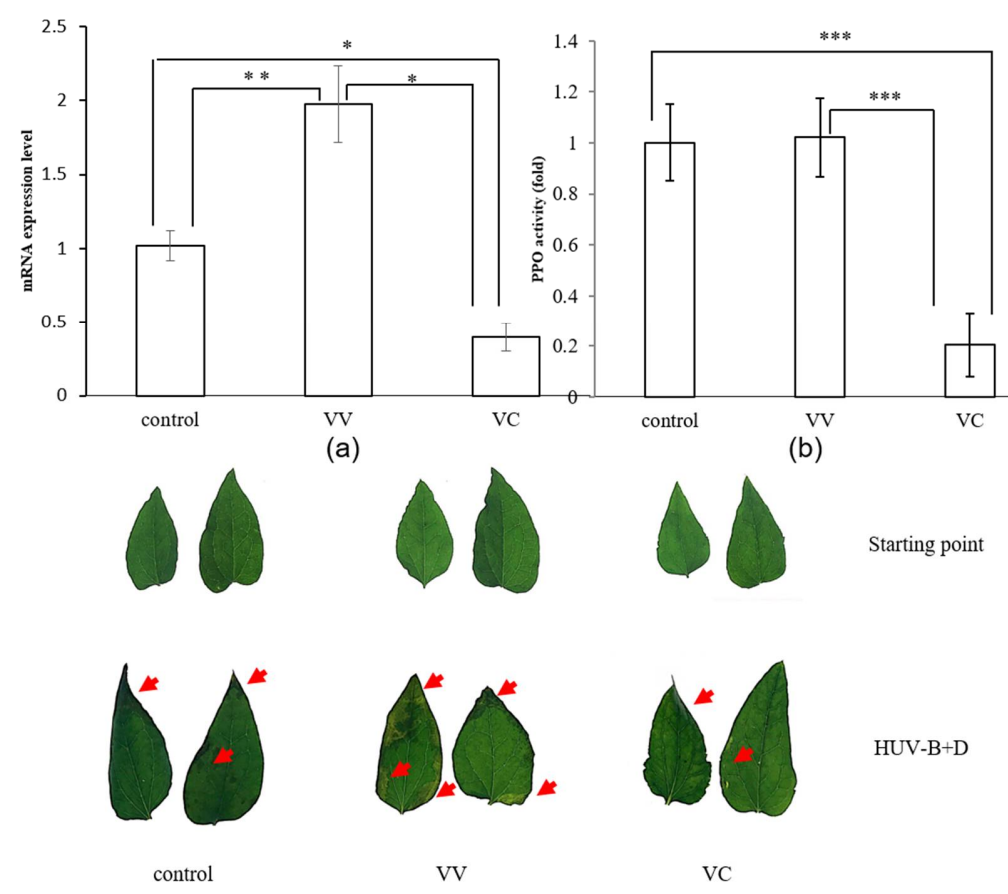

(c)

Figure 1. (a) Expression levels of CtPPO gene mRNA in leaves of C. terniflora in control, VIGS-vector, and VIGS-CtPPO plants. Data are shown as mean \pm SD of the independent biological replicates. Asterisks indicate significant changes as measured by Student's t-test $\left({ }^{*} p<0.05,{ }^{* *} p<0.01\right.$, and $\left.{ }^{* * *} p<0.001\right)$; (b) PPO activity was assayed in C. terniflora leaves of control, VIGS- vector and VIGS-CtPPO plants. Data are shown as mean \pm SD of independent biological replicates. Asterisks indicate significant changes as measured by Student's $t$-test $\left({ }^{*} p<0.05,{ }^{* *} p<0.01\right.$, and $\left.{ }^{* * *} p<0.001\right)$; (c) Morphology of control, VIGS-vector, and VIGS-CtPPO C. terniflora plants before and after HUV-B+D treatment. Photograph showing C. terniflora growth under different treatments. The damaged areas were marked with red arrows. 


\subsection{Effects of VIGS-CtPPO and VIGS-Vector on Leaf Proteins in C. terniflora DC.}

To investigate the effects of CtPPO on C. terniflora leaf proteins, a gel-free/label-free proteomic technique was used. Proteins extracted from VC- and VV-infected C. terniflora leaves were reduced, alkylated, digested, and analyzed by nano-LC-MS/MS. The obtained proteomic data were analyzed using the UniProtKB/Swiss-Prot database and protein content was estimated by $\mathrm{mol} \%$. The functions of identified proteins were predicted based on comparisons with functional annotations of the Arabidopsis genome and classified using MapMan bin codes. The results of the functional analyses demonstrated that the proteins with increased expression were mainly enriched in photosynthesis, glycolysis, redox, protein metabolism, and secondary metabolism, while the proteins with decreased expression were mainly enriched in protein metabolism and photosynthesis. Notably, expression of proteins related to secondary metabolism, development, and glycolysis were increased in the VC plants, whereas the expression of proteins related to N-metabolism, amino acid metabolism, and cell were decreased (Figure 2a; Tables S8 and S9).

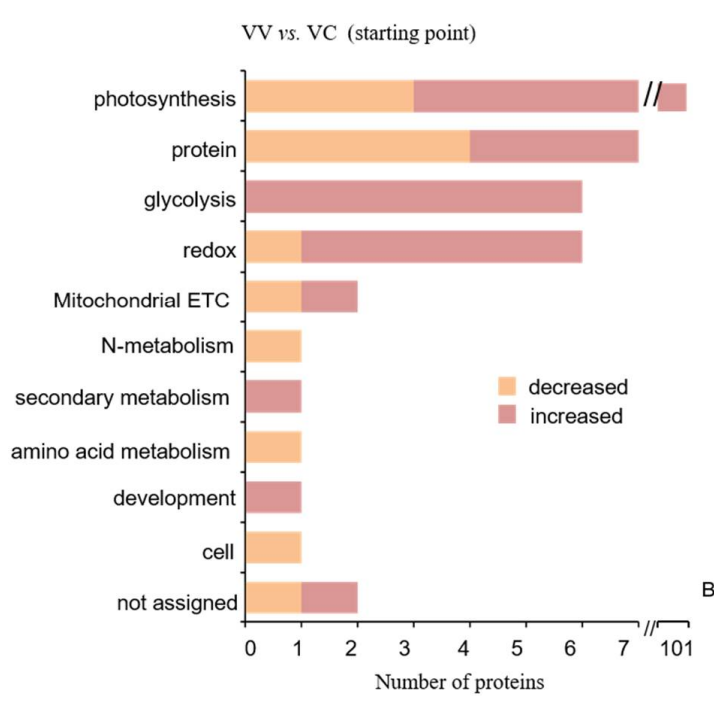

(a)

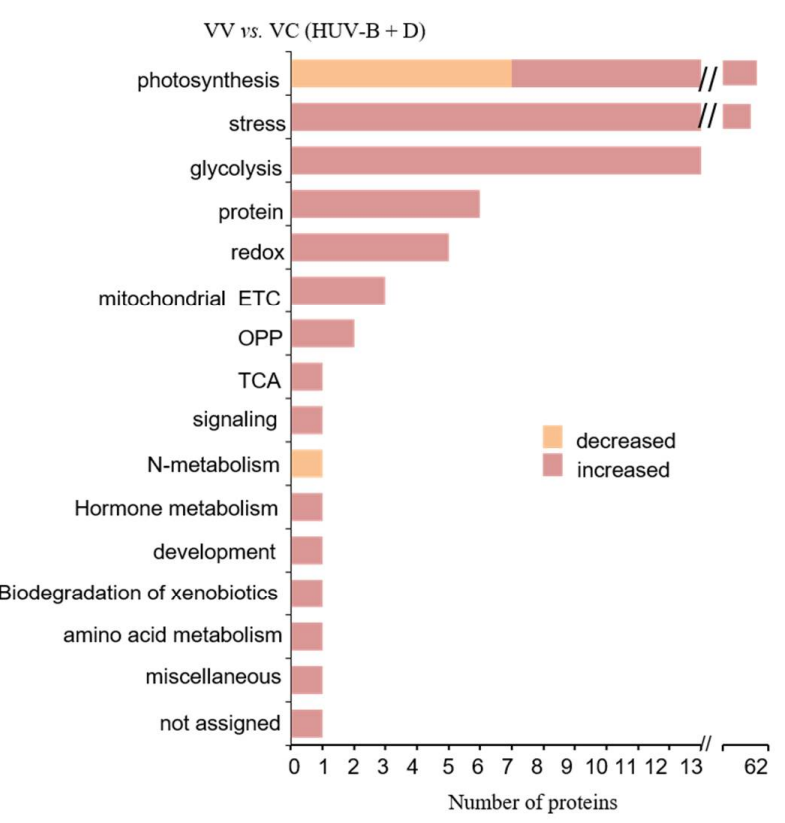

(b)

Figure 2. (a,b) Functional distribution of proteins identified in VIGS-vector and VIGS-CtPPO C. terniflora DC. leaves. The leaves were collected at the (a) starting point and (b) after HUV-B treatment. Proteins were extracted, reduced, alkylated, digested, and analyzed by nanoLC-MS/MS. Protein content is reported as mol \%. Protein functions were predicted and categorized using MapMan bin codes. Abbreviations: cell, cell division/organization/cycle; TCA, tricarboxylic acid; ETC, electron transport chains; OPP, oxidative pentose phosphate.

2.4. Effects of High-Level UV-B and Dark Treatment on Proteins in VIGS-CtPPO and VIGS-Vector C. terniflora DC. Leaves

HUV-B+D dramatically impacts plant physiology [24]. To further investigate the effects of CtPPO on C. terniflora, we exposed VC, VV, and control plants to HUV-B+D. Subsequent phenotypic analysis revealed the leaves to be wilted with burned patches and a high degree of crispation in control plants. The leaves of VV plants were similar to the control plants, while the leaves from the VC plants appeared significantly less damaged than in the control and VV plants (Figure 1c). To determine the expression profiles of leaf proteins in VC and VV after HUV-B+D, a gel-free/label-free proteomic approach was used. Proteins extracted from VC and VV plant leaves after HUV-B+D were reduced, alkylated, digested, and analyzed by nano-LC-MS/MS. Obtained proteomic data were analyzed using the UniProtKB/Swiss-Prot database and the protein content was estimated by $\mathrm{mol} \%$. The functions of 
identified proteins were predicted based on comparisons with functional annotations of the Arabidopsis genome and classified using MapMan bin codes. The results of the functional analyses demonstrated that HUV-B+D increased expression of proteins involved in most of the functional classes, including photosynthesis, stress, glycolysis, protein metabolism, and redox, in VC plants compared to VV plants. However, expression of proteins involved in N-metabolism was decreased in VC plants compared to VV plants (Figure 2b).

\subsection{Integrated Analysis of Proteins in VIGS-CtPPO and VIGS-Vector C. terniflora Differentially Expressed after $H U V-B+D$}

The proteins identified in leaves collected from VC and VV plants at the starting point were 676 and 662, respectively. Among the identified proteins, 480 and 467 proteins were commonly expressed in VV and VC plants, respectively, at the starting point and after HUV-B+D. Alternatively, there were 443 and 455 proteins commonly expressed at the starting point and HUV-B+D in VV and VC plants, respectively (Figure S3).

For proteins differentially expressed in response to HUV-B+D in VV and VC plants, further integration analysis was performed. Figure 3 shows that the number of proteins involved in photosynthesis displaying increased expression was decreased in VC plants compared with that in VV plants. The number of increased proteins related to stress, OPP, secondary metabolism, and transport was increased in VC plants compared to VV plants. The number of decreased proteins associated with stress, glycolysis, amino acid metabolism, and carbon-one(C1)-metabolism was decreased in VC plants compared to VV plants. Furthermore, proteins involved in glycolysis, amino acid metabolism, cell, mitochondrial ETC, TCA, and signaling displaying increased expression were only detected in VC plants (Figure 3, Tables S6 and S7).

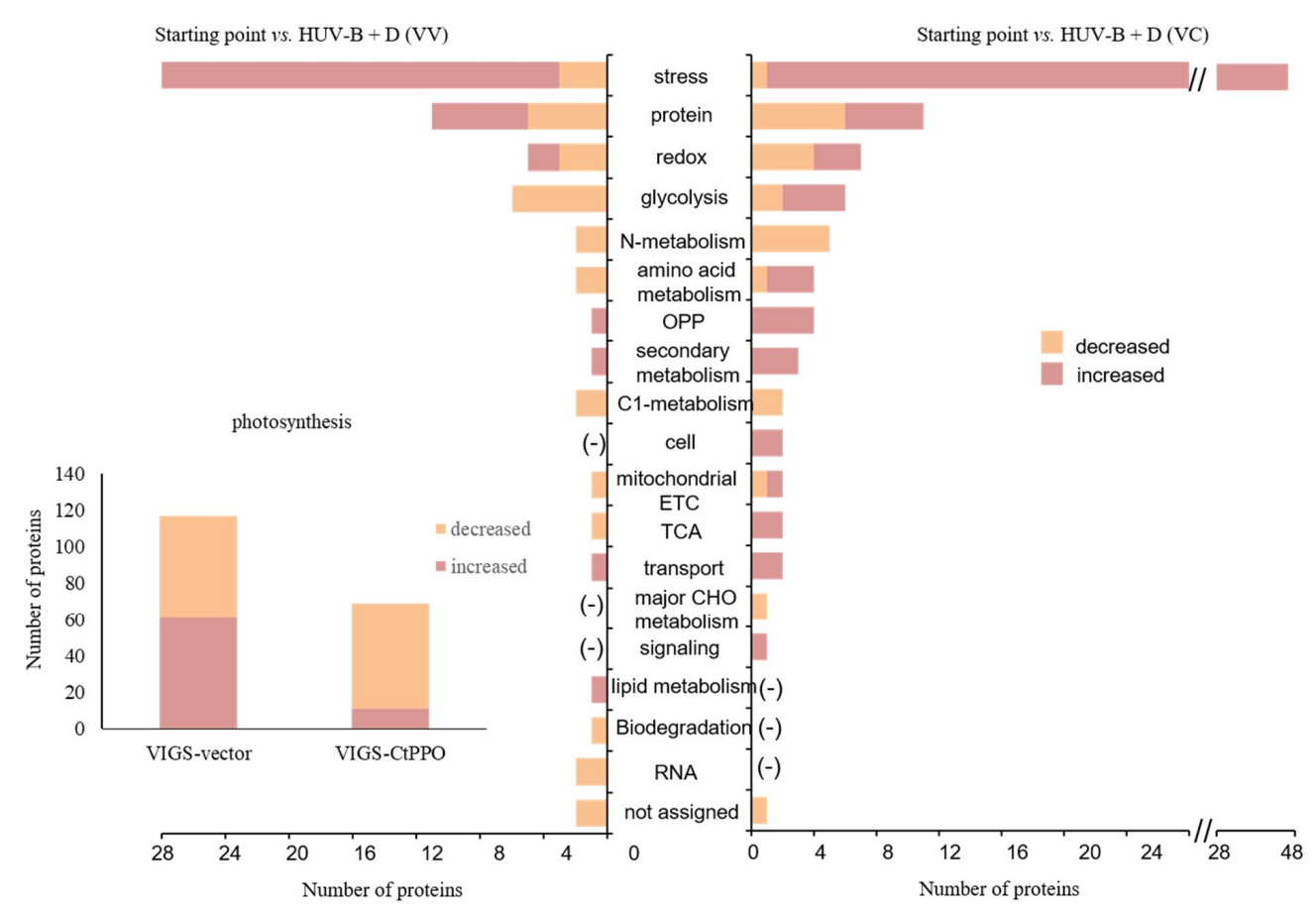

Figure 3. Functional distribution of proteins identified in VIGS-vector and VIGS-CtPPO C. terniflora DC. leaves. Leaves were collected at the starting point and after HUV-B+D treatment. Proteins were extracted, reduced, alkylated, digested, and analyzed by nanoLC-MS/MS. Protein content is reported as $\mathrm{mol} \%$. Protein functions were predicted and categorized using MapMan bin codes. Abbreviations: cell, cell division/organization/cycle; TCA, tricarboxylic acid; ETC, electron transport chains; CHO, carbohydrate; OPP, oxidative pentose phosphate; (-), not determined. 
2.6. MapMan Analysis of the VIGS-CtPPO and VIGS-Vector C. terniflora Leaf Proteomic Data at the Starting Point and after $H U V-B+D$

To examine changes in the levels of the identified proteins in-depth in VV and VC plants, the DEPs were analyzed using MapMan software. The analysis identified the main functional categories of the proteins displaying significant changes in expression as involved in the light reaction, photorespiration, and Calvin cycle. HUV-B+D conditions induced dramatic decrease in Calvin cycle and light reaction related proteins in $\mathrm{VV}$, however, very interestingly, it was significantly rescued by the silencing of $\mathrm{CtPPO}$ in VC. Further analysis showed that the silencing of CtPPO led to the increase of Calvin cycle related proteins in $\mathrm{VC}$ than $\mathrm{VV}$ at starting point (Figure $4 \mathrm{a}, \mathrm{b}$ ). After exploring $\mathrm{HUV}-\mathrm{B}+\mathrm{D}$, the silencing of CtPPO gave a further increase of Calvin cycle related proteins. Additionally, it also resulted in the synchronously increase on light reaction and photorespiration related proteins in $\mathrm{VC}$ than $\mathrm{VV}$ at HUV-B+D (Figure 4c,d).

a. VV at HUV-B+D vs. starting point

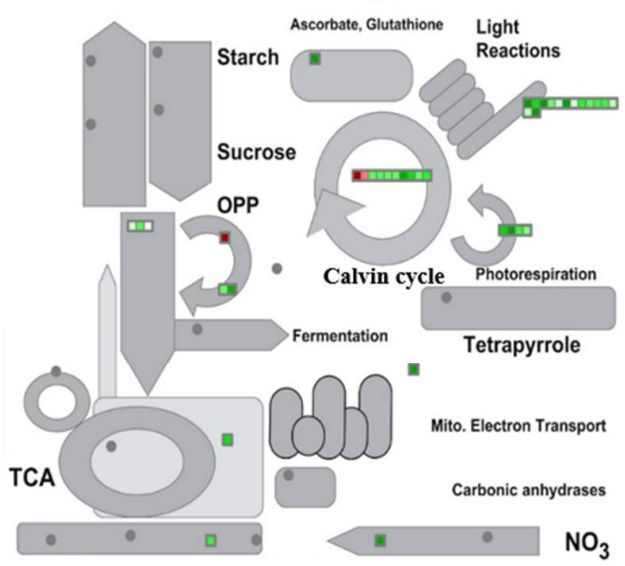

c. VC vs. VV at starting point

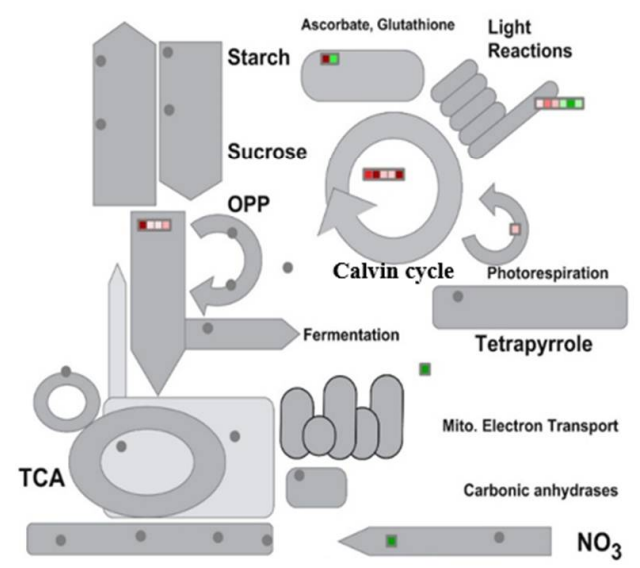

b. VC at HUV-B+D vs. starting point

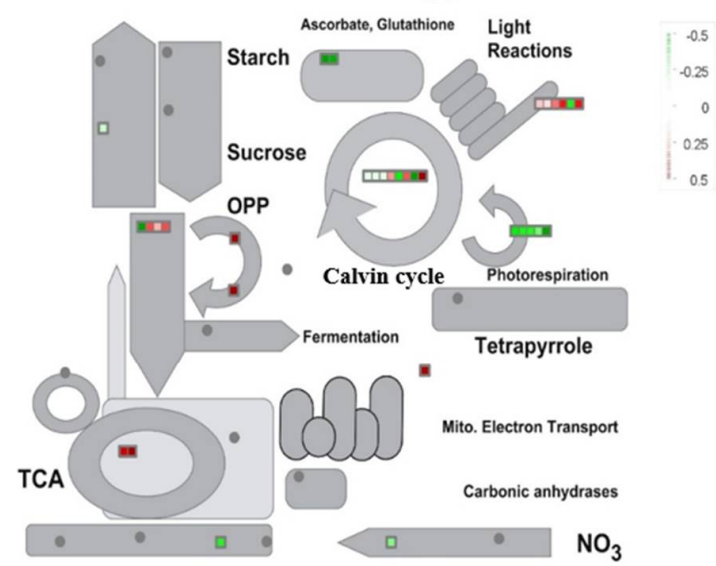

d. VC vs. VV after HUV-B+D

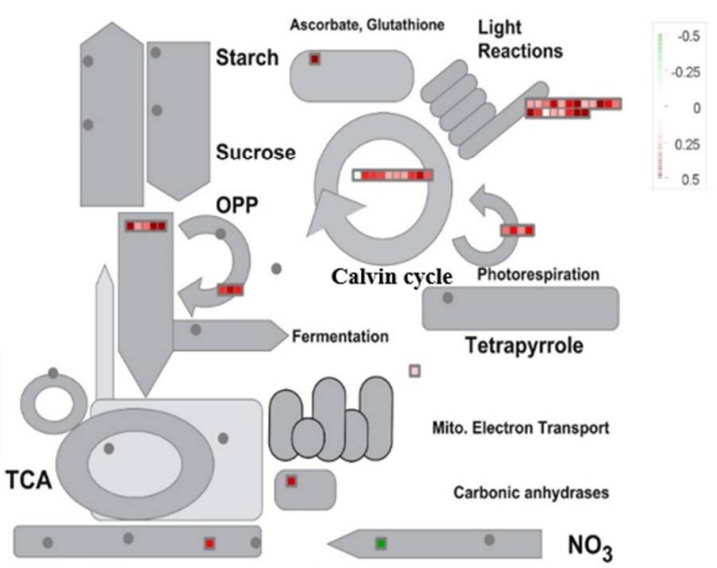

Figure 4. Metabolic pathways of proteins identified in VIGS-vector and VIGS-CtPPO C. terniflora DC. Leaves were collected at the starting point and after HUV-B+D treatment. The proteins were grouped into functional categories related to primary metabolism and changes in abundance were visualized using MapMan software. Each square and color indicates the fold-change of a differentially expressed protein. Green and red indicate a decrease and increase, respectively, in fold change compared with the corresponding group: (a) comparison of proteins in VIGS-vector leaves after HUV-B+D treatment at starting point, (b) comparison of proteins in VIGS-CtPPO leaves after HUV-B+D treatment at starting point, (c) comparison of proteins at starting point in VIGS-CtPPO and VIGS-vector plants, and (d) comparison of proteins after HUV-B+D treatment in VIGS-CtPPO and VIGS-vector plants. Abbreviations: OPP, oxidative pentose phosphate; $\mathrm{CHO}$, carbohydrate; TCA, tricarboxylic acid cycle. 
Following this preliminary analysis, we further studied the differences in enzymes in the light reaction and Calvin cycle. The proteins involved in the light reaction and Calvin cycle was mostly decreased in VV but there was no obvious change in VC after HUV-B+D treatment. At starting point, 1 and 3 proteins in photosystem I and II of light reaction was increased in VC compared to VV. In Calvin cycle, 3 and 2 proteins involved in carboxylation and reduction was increased in VC compared with VV. However, after HUV-B+D treatment, 19 proteins related to $\mathrm{NADP}^{+}$-dependent aldehyde reductase, ATP synthase, and glycerol phosphate dehydrogenase in light reactions was increased and 11 proteins related to the enzymes in reduction and regeneration of Calvin cycle was increased in comparison of VC and VV (Figure S4).

\subsection{Expression Profile Analysis of Glycolysis-Related Proteins in C. terniflora DC. Leaves}

Glycolysis related proteins were significantly changed by the silencing of CtPPO. To further characterize the relationship between glycolysis and CtPPO, expression profile analysis of glycolysis-related proteins in C. terniclora leaves was conducted. The abundances of glyceraldehyde-3-phosphate dehydrogenase (GAPDH), UTP-glucose-1-phosphate uridylytransferase (GPUT), phosphoglycerate kinase (PGK), phosphoenolpyruvate carboxylase (PEPC), and enolase were increased in VC plants compared to VV plants at the starting point. Moreover, after HUV-B+D, the abundances of GPUT, fructose-1,6-bisphosphate aldolase (FBA), GAPDH, PGK, BPGM, enolase, and PEPC were all increased in VC plants compared to VV plants (Figure 5).

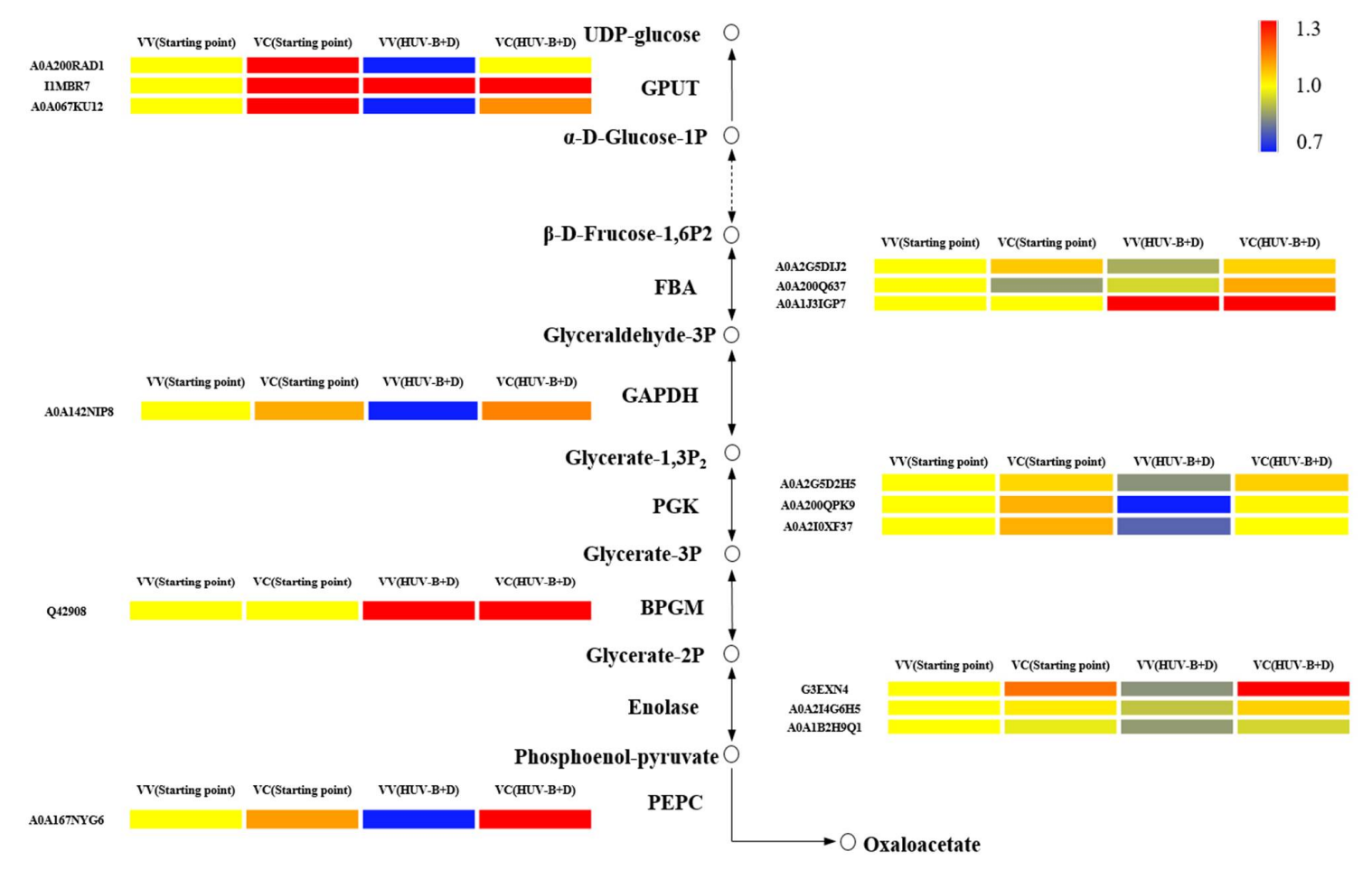

Figure 5. Expression profile analysis of glycolysis-associated proteins. Each square and color indicates the fold-change for a differentially expressed protein. Blue and red indicate a decrease and increase, respectively, in fold-change compared with the corresponding group: VV(SP) proteins in VIGS-vector plants at starting point, VC(SP) proteins in VIGS-CtPPO plants at starting point, VV(HUV-B+D) proteins in VIGS-vector plants after HUV-B+D treatment, and VC(HUV-B+D) proteins in VIGS-CtPPO plants after HUV-B+D treatment. FBA: fructose-1,6-bisphosphate aldolase; GAPDH: glyceraldehyde-3-phosphate dehydrogenase; PEPC: phosphoenolpyruvate carboxylase; circle: metabolite; arrow: direction; solid line: single step; dotted line: multiple step. 


\subsection{Effects of VIGS-CtPPO on Photosynthesis Characteristics in C. terniflora DC. Leaves}

To confirm the relationship between CtPPO and photosynthesis, the chlorophyll content was measured first. The results showed that the chlorophyll $a$, chlorophyll $b$, and total chlorophyll contents were all higher in VC plants than in VV and control plants (Figure 6). Then the photosynthesis characteristics were measured by using a Li-6400 Portable Photosynthesis System.

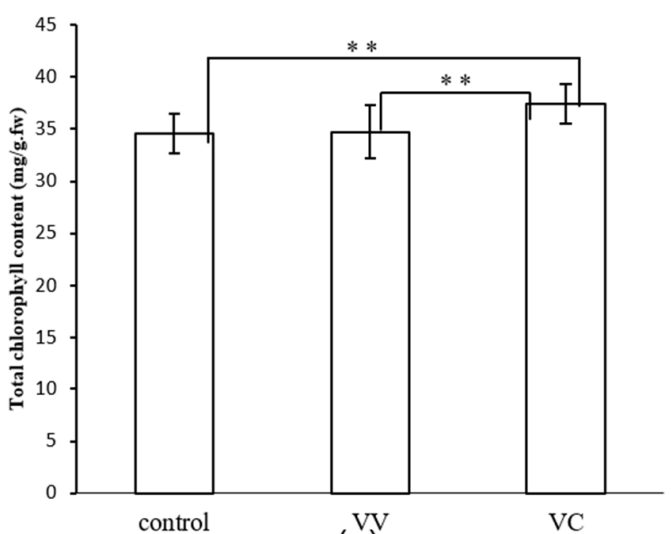

(a)

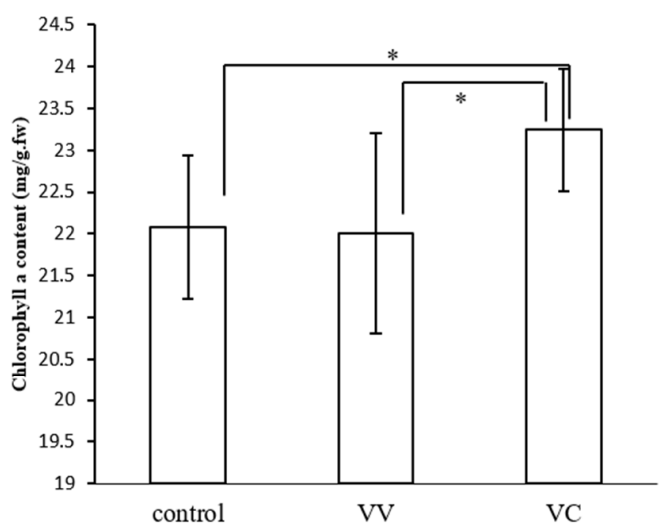

(b)

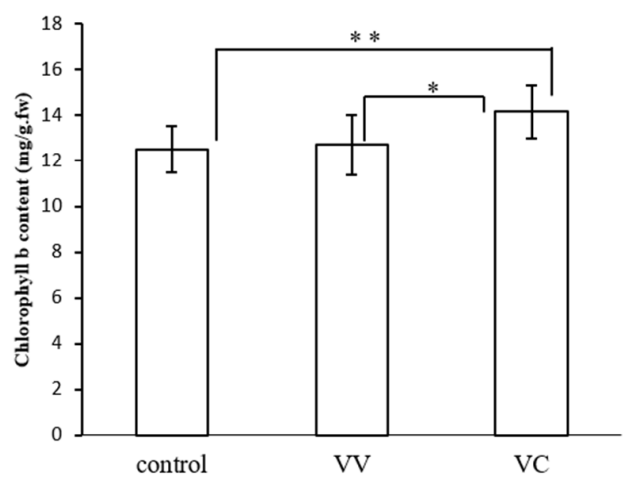

(c)

Figure 6. Chlorophyll content in in control, VIGS- vector and VIGS-CtPPO C. terniflora leaves. (a) Total chlorophyll content, (b) chlorophyll a content, and (c) chlorophyll b content. Data are shown as mean $\pm \mathrm{SD}$ for independent biological replicates. Asterisks indicate significant changes as measured by Student's $t$-test $\left.{ }^{*} p<0.05,{ }^{* *} p<0.01\right)$. fw: fresh weight.

The photosynthesis rate, intercellular $\mathrm{CO}_{2}$, stomatal conductance, and transpiration rate were further measured in the study. The photosynthesis rate, transpiration rate, and stomatal conductance in VC plants were higher than in VV plants, while the intercellular $\mathrm{CO}_{2}$ was lower than that in VV (Figure 7). After HUV-B+D, the damage of photosynthesis rate in VC plants was significantly lower than in $\mathrm{VV}$ and control plants, while the stomatal conductance and transpiration rate were low in control, VV, and VC plants. The intercellular $\mathrm{CO}_{2}$ was still lower in $\mathrm{VC}$ and control plants than in VV plants, but both were higher than that at the starting point (Figure S5). The photosynthesis rate was dramatically decreased in by HUV-B+D in C. terniflora, however, it seems that the silencing of CtPPO has a mitigating effect to the damage degree in VC (Figure 7 and Figure S5). 

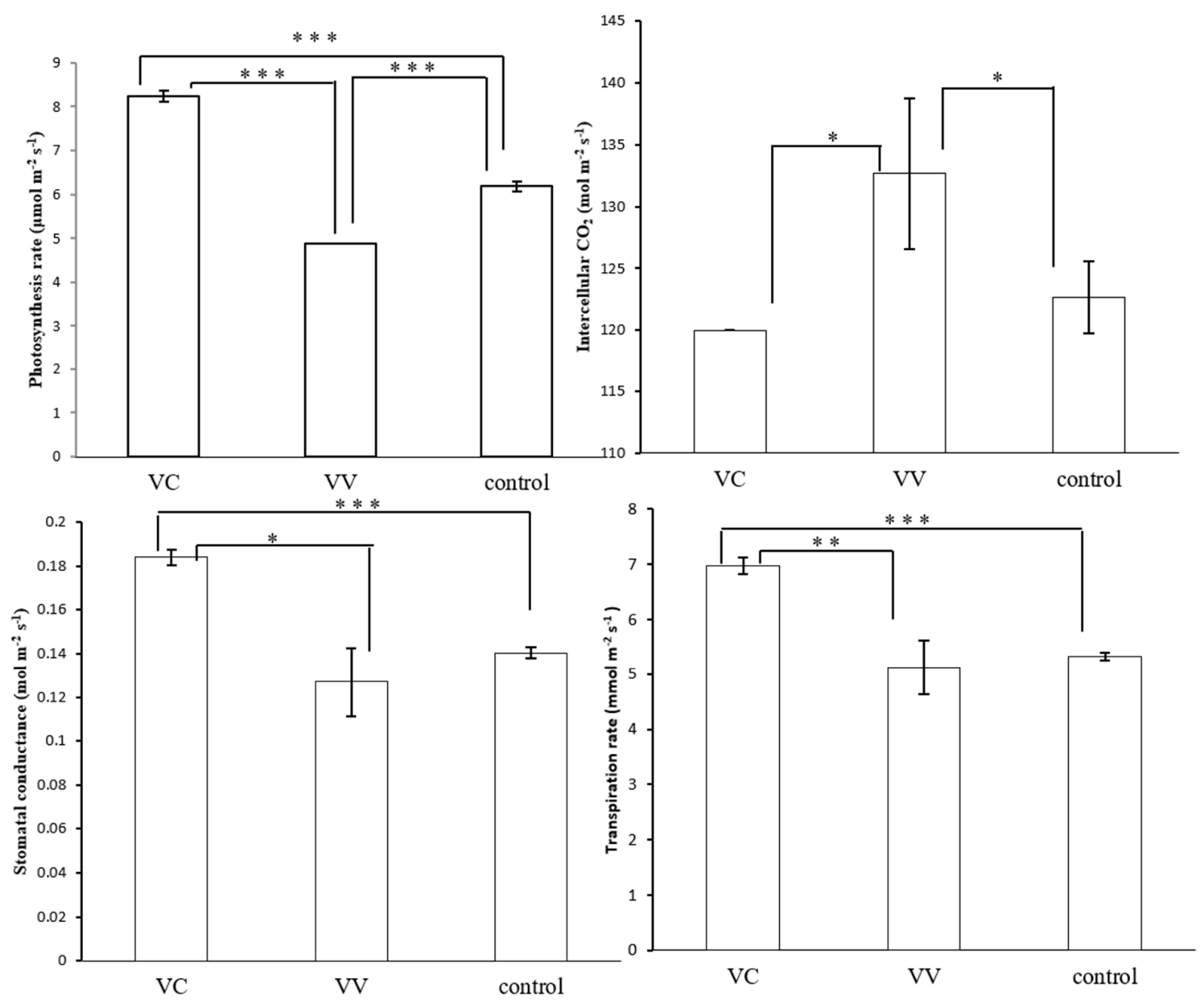

Figure 7. Analysis of photosynthesis characteristics in control, VIGS-vector, and VIGS-CtPPO at starting point. The photosynthesis rate, intercellular $\mathrm{CO}_{2}$, stomatal conductance, and transpiration rate were measured using an open gas-exchange system. Data are shown as mean $\pm \mathrm{SD}$ of independent biological replicates. Asterisks indicate significant changes as measured by Student's $t$-test $\left({ }^{*} p<0.05\right.$, ** $p<0.01$, and $\left.{ }^{* * *} p<0.001\right)$.

\subsection{Effects of VIGS-CtPPO on ATP Synthase in C. terniflora DC. Leaves}

To confirm the relationship between CtPPO and energy metabolism, qRT-PCR-based analysis of ATP synthase was performed. Leaves of VV and VC were collected at starting point and after HUV-B+D. At the starting point, the expression of ATP synthase was increased without statistical significance in VC compared with control and VV (Figure 8). However, after HUV-B+D, ATP synthase was increased by 2-folds in VC plants compared with VV and control plants (Figure 8). These results indicate that the silencing of CtPPO might activate the energy metabolism by up-regulating the ATP synthase in response to HUV-B+D. 


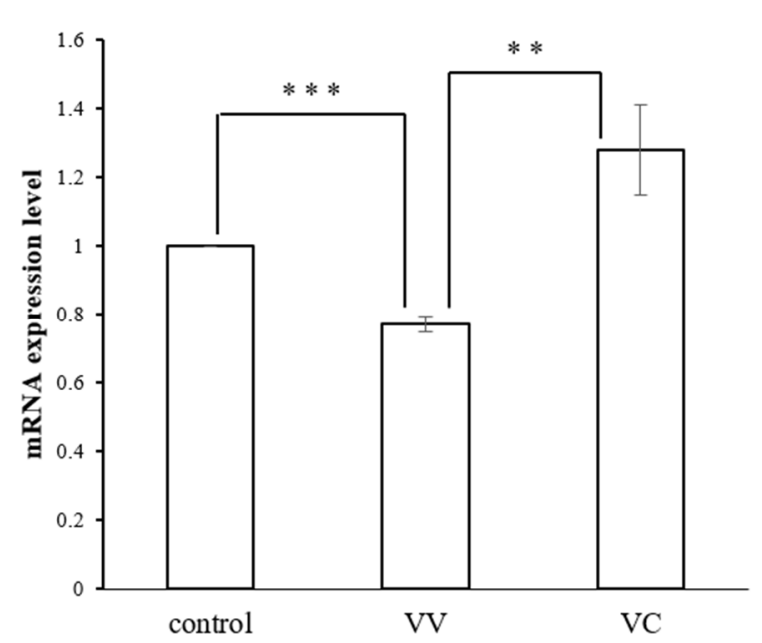

(a)

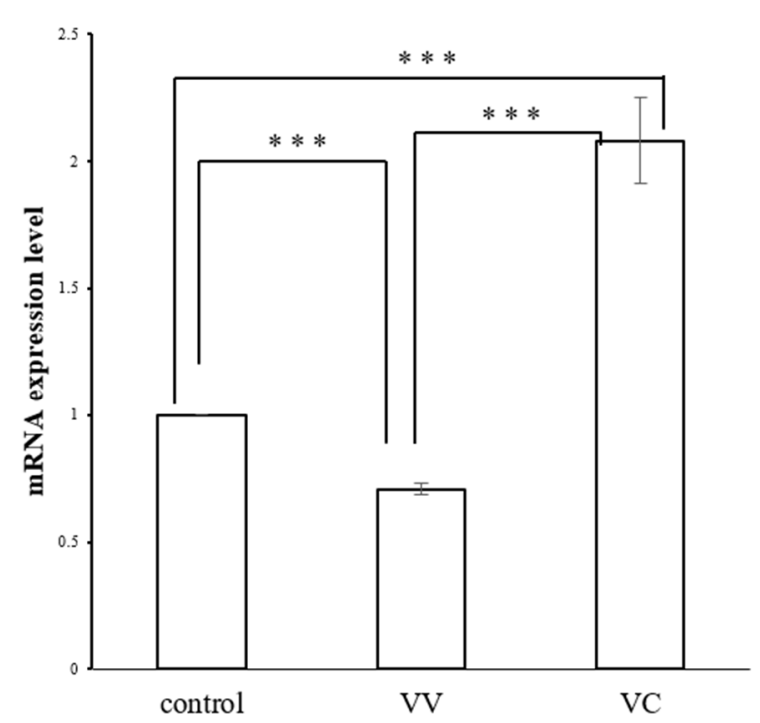

(b)

Figure 8. Levels of chloroplast ATP synthase mRNA in control, VIGS-vector, and VIGS-CtPPO C. terniflora leaves. (a,b) C. terniflora leaves at the (a) starting point and (b) after HUV-B+D treatment. Data are shown as mean $\pm \mathrm{SD}$ of independent biological replicates. Asterisks indicate significant changes as measured by Student's $t$-test $\left(* * p<0.01\right.$, and $\left.{ }^{* * *} p<0.001\right)$.

\section{Discussion}

\subsection{Silencing of PPO Promoted the Light Reaction in C. terniflora}

The photosynthetic process in plants can operate through linear or cyclic electron flow, which involves three major complexes of the electron transfer chain: photosystem II (PSII), photosystem I (PSI), and cytochrome b6f complex [29,30]. Light reactions are an important step in photosynthesis and can transfer light energy to ATP and NADPH [31]. The initial step in this process is the absorption of light energy by the chlorophyll molecule. Ferredoxins were extensively employed as electron shuttles by anaerobes long before the advent of oxygenic photosynthesis [32], while the ferredoxin-NADP ${ }^{+}$ reductase catalyzes an electron-hydride exchange between reduced ferredoxin and $\mathrm{NADP}^{+}$to yield NADPH [33]. The activation state of chloroplast ATP synthase is regulated by proton-motive forces generated by photosynthetic electron transfer reactions and reduction of disulphides in the $\gamma$ subunit by TRX [34,35]. A lower ATP content resulting from the loss of ATP synthesis can inhibit the synthesis of ribulose biphosphate and influence the photosynthetic assimilation of $\mathrm{CO}_{2}$ [36]. In our study, the amounts of chlorophyll a and chlorophyll $b$ were increased in VC plants compared with the VV and control plants, indicating the silencing of CtPPO could upregulate the PSs system in photosynthesis. In addition, the expression of ATP synthase, and ferredoxin-NADP ${ }^{+}$reductase were decreased in response to HUV-B+D (Table S6), indicating the inhibition effect of HUV-B+D on C. terniflora. However, the expression of ATP synthase (Figure 8 ) and ferredoxin-NADP ${ }^{+}$reductase (Table 1) were dramatically increased in VC plants compared with VV plants after HUV-B+D. These results indicate that VIGS of CtPPO had a positive effect on upregulating the light reactions to provide ATP and NADPH for plants under stress. 
Table 1. Differential Expressed Proteins in Clematis terniflora DC. between VV and VC after HUV-B+D treatment $(1.55>$ fold change $>1.27)$.

\begin{tabular}{|c|c|c|c|c|c|c|c|}
\hline \multirow{2}{*}{ No. } & \multirow{2}{*}{ Protein ID $^{a}$} & \multirow{2}{*}{ Description } & \multicolumn{2}{|c|}{ Abundance } & \multirow{2}{*}{ FC } & \multirow{2}{*}{$p$-Value } & \multirow{2}{*}{ Annotation $^{\mathbf{b}}$} \\
\hline & & & VV & VC & & & \\
\hline & Increased & & & & & & \\
\hline 1 & F6HCT7 & Uncharacterized protein & 0.01 & 0.02 & 1.55 & 0.01 & stress \\
\hline 2 & M5W912 & Ferredoxin-NADP reductase & 0.04 & 0.06 & 1.51 & 0.00 & PS \\
\hline 3 & A0A2G5CER3 & Uncharacterized protein (Fragment) & 0.01 & 0.01 & 1.50 & 0.03 & signaling \\
\hline 4 & A0A200RAD1 & $\begin{array}{l}\text { UTP-glucose-1-phosphate } \\
\text { uridylyltransferase }\end{array}$ & 0.02 & 0.03 & 1.48 & 0.03 & glycolysis \\
\hline 5 & I6P9I5 & $\begin{array}{l}\text { Cytosolic ascorbate peroxidase } \\
\text { (Fragment) }\end{array}$ & 0.03 & 0.04 & 1.47 & 0.02 & redox \\
\hline 6 & J3MAL0 & Ferredoxin-NADP reductase & 0.04 & 0.06 & 1.47 & 0.00 & PS \\
\hline 7 & M4CGU3 & Uncharacterized protein & 0.02 & 0.02 & 1.45 & 0.02 & PS \\
\hline 8 & Q42908 & $\begin{array}{l}\text { 2,3-bisphosphoglycerate-independent } \\
\text { phosphoglycerate mutase }\end{array}$ & 0.01 & 0.02 & 1.42 & 0.04 & glycolysis \\
\hline 9 & A0A1J3H2G2 & $\begin{array}{l}\text { Ubiquitin-NEDD8-like protein RUB1 } \\
\text { (Fragment) }\end{array}$ & 0.27 & 0.38 & 1.40 & 0.01 & protein \\
\hline 10 & A0A2G5F096 & Uncharacterized protein & 0.02 & 0.03 & 1.40 & 0.05 & development \\
\hline 11 & C5YTC0 & Uncharacterized protein & 0.02 & 0.03 & 1.39 & 0.00 & not assigned \\
\hline 12 & A0A067L6G5 & Uncharacterized protein & 0.02 & 0.03 & 1.39 & 0.00 & $\begin{array}{l}\text { amino acid } \\
\text { metabolism }\end{array}$ \\
\hline 13 & W9RXI1 & Glycerate dehydrogenase & 0.08 & 0.11 & 1.38 & 0.00 & PS \\
\hline 14 & Q1EP00 & $\begin{array}{l}\text { Chlorophyll a-b binding protein, } \\
\text { chloroplastic }\end{array}$ & 0.05 & 0.07 & 1.37 & 0.03 & PS \\
\hline 15 & W9SCQ6 & Ferredoxin-NADP reductase & 0.05 & 0.07 & 1.36 & 0.00 & PS \\
\hline 16 & A0A2G5DAJ3 & Carbonic anhydrase & 0.03 & 0.04 & 1.36 & 0.04 & TCA \\
\hline 17 & W8TP69 & Glycerate dehydrogenase-like protein & 0.04 & 0.06 & 1.36 & 0.02 & PS \\
\hline 18 & A0A0K9P513 & Phosphoglycerate kinase & 0.08 & 0.10 & 1.35 & 0.01 & PS \\
\hline 19 & A0A0K9Q3W1 & $70 \mathrm{kDa}$ heat shock protein & 0.06 & 0.07 & 1.35 & 0.01 & stress \\
\hline 20 & A0A1J6I7J0 & 2-cys peroxiredoxin bas1, chloroplastic & 0.05 & 0.07 & 1.35 & 0.01 & redox \\
\hline 21 & COPRVO & Lactoylglutathione lyase & 0.03 & 0.04 & 1.33 & 0.02 & $\begin{array}{l}\text { Biodegradation } \\
\text { of Xenobiotics }\end{array}$ \\
\hline 22 & Q19U04 & $\begin{array}{l}\text { NADH-dependent hydroxypyruvate } \\
\text { reductase (Fragment) }\end{array}$ & 0.11 & 0.15 & 1.33 & 0.00 & PS \\
\hline 23 & D2XUU3 & $\begin{array}{c}\text { Chloroplast managanese stabilizing } \\
\text { protein (Fragment) }\end{array}$ & 0.17 & 0.22 & 1.32 & 0.04 & PS \\
\hline 24 & A0A0A0KBL8 & Uncharacterized protein & 0.03 & 0.04 & 1.32 & 0.00 & PS \\
\hline 25 & A5BVF4 & Uncharacterized protein & 0.16 & 0.21 & 1.32 & 0.02 & PS \\
\hline 26 & A0A200QG47 & Aminotransferase & 0.05 & 0.06 & 1.32 & 0.02 & PS \\
\hline 27 & W1P8B5 & Uncharacterized protein & 0.01 & 0.01 & 1.31 & 0.05 & OPP \\
\hline 28 & A0A0D3B1C7 & Uncharacterized protein & 0.02 & 0.02 & 1.30 & 0.02 & OPP \\
\hline 29 & К7КВ09 & Uncharacterized protein & 0.03 & 0.04 & 1.30 & 0.01 & $\begin{array}{l}\text { hormone } \\
\text { metabolism }\end{array}$ \\
\hline 30 & K4BW79 & 2-methylene-furan-3-one reductase & 0.06 & 0.07 & 1.30 & 0.00 & misc \\
\hline 31 & A0A2H5NQP8 & Uncharacterized protein & 0.08 & 0.10 & 1.30 & 0.01 & PS \\
\hline 32 & A0A0D2Q3K9 & Uncharacterized protein & 0.04 & 0.05 & 1.30 & 0.00 & stress \\
\hline 33 & A0A200PYZ1 & ATPase & 0.08 & 0.11 & 1.29 & 0.01 & PS \\
\hline 34 & A1BQW9 & Transketolase (Fragment) & 0.05 & 0.06 & 1.29 & 0.00 & PS \\
\hline 35 & A0A251VGE5 & Putative photosystem I PsaA/PsaB & 0.05 & 0.06 & 1.29 & 0.03 & PS \\
\hline 36 & A0A1D8H339 & 2-Cys peroxiredoxin & 0.07 & 0.09 & 1.28 & 0.01 & redox \\
\hline 37 & S8EAM3 & Heat shock protein hsp70 (Fragment) & 0.03 & 0.03 & 1.28 & 0.00 & stress \\
\hline
\end{tabular}

${ }^{a}$ Protein ID, according to UniProtKB/Swiss-Prot database. ${ }^{b}$ Function, protein function categorized using MapMan bin codes. FC, fold change; PS, photosynthesis; TCA, tricarboxylic acid; OPP, oxidative pentose phosphate; misc: miscellaneous. 


\subsection{Silencing of $P P O$ Activated the Calvin Cycle in C. terniflora}

The Calvin cycle is an essential carbon fixation process in photosynthesis that converts carbon dioxide to glucose, accompanied by reduction reactions and ribulose 1,5-bisphosphate (RuBP) regeneration [37]. The Calvin cycle is redox-activated process, and the redox homeostasis is mediated by reducing power from photosynthetic electron transport to ferredoxin (Fd) and NADPH, via Fd-thioredoxin (TRX) reductase (FTR) and NADPH-dependent TRX reductase (NTRC) [38]. FTR and multiple TRXs consist the Fd-TRX system, while the NTRC contains a complete TRX system in a single polypeptide. Both systems have an impact on activation of Calvin cycle-related enzymes, including fructose-1,6-bisphosphatase (FBPase), sedoheptulose-1,7-bisphosphatase (SBPase), phosphoribulokinase (PRK), and GAPDH [39-41]. In our current study, Calvin cycle-related PGK, GAPDH, PRK, TK, and RuBP were decreased in response to HUV-B+D, indicating HUV-B+D significantly inhibited the Calvin cycle. However, the drop in CtPPO activity led to a dramatic increase in Calvin cycle-related proteins in C. terniflora at the starting point and after HUV-B+D. The redox-related proteins were further analyzed and TRX was found to be increased in VC plants compared with VV plants at the starting point (Table 2) and Fd-NADP reductase was increased in VC plants compared to VV plants after HUV-B+D (Table 1). As PPO is located in chloroplast [42,43], these results indicate VIGS of CtPPO can protect the Calvin cycle by activating the FTR and NTRC system.

Table 2. Differential Expressed Proteins in Clematis terniflora DC. between VV and VC at starting point (fold change $>1.40$ ).

\begin{tabular}{|c|c|c|c|c|c|c|c|}
\hline \multirow{2}{*}{ No. } & \multirow{2}{*}{ Protein ID ${ }^{a}$} & \multirow{2}{*}{ Description } & \multicolumn{2}{|c|}{ Abundance } & \multirow{2}{*}{ FC } & \multirow{2}{*}{$p$-Value } & \multirow{2}{*}{ Annotation } \\
\hline & & & VV & VC & & & \\
\hline \multicolumn{8}{|c|}{ Increased } \\
\hline 1 & A0A151U9E4 & Uncharacterized protein & 0.02 & 0.03 & 1.92 & 0.01 & redox \\
\hline 2 & Q8M9K2 & $\begin{array}{l}\text { Ribulose-bisphosphate carboxylase } \\
\text { (Fragment) }\end{array}$ & 0.79 & 1.46 & 1.84 & 0.00 & PS \\
\hline 3 & K8ECB3 & Thioredoxin & 0.04 & 0.08 & 1.82 & 0.00 & redox \\
\hline 4 & A0A067KU12 & $\begin{array}{l}\text { UTP-glucose-1-phosphate } \\
\text { uridylyltransferase }\end{array}$ & 0.03 & 0.04 & 1.57 & 0.02 & glycolysis \\
\hline 5 & A0A068TPY5 & Uncharacterized protein & 0.03 & 0.05 & 1.53 & 0.01 & PS \\
\hline 6 & A0A2G3DEA2 & $\begin{array}{l}\text { 3-oxo-Delta(4,5)-steroid } \\
\text { 5-beta-reductase }\end{array}$ & 0.03 & 0.04 & 1.45 & 0.02 & development \\
\hline 7 & A1X444 & $\begin{array}{l}\text { Ribulose-1,5-bisphosphate } \\
\text { carboxylase/oxygenase large }\end{array}$ & 0.27 & 0.39 & 1.44 & 0.00 & PS \\
\hline 8 & A0A1U8LIR6 & $\begin{array}{l}\text { 2-methyl-6-phytyl-1,4-hydroquinone } \\
\text { methyltransferase }\end{array}$ & 0.02 & 0.02 & 1.43 & 0.01 & $\begin{array}{l}\text { secondary } \\
\text { metabolism }\end{array}$ \\
\hline 9 & A0A200RAD1 & $\begin{array}{l}\text { UTP-glucose-1-phosphate } \\
\text { uridylyltransferase }\end{array}$ & 0.03 & 0.04 & 1.42 & 0.04 & glycolysis \\
\hline 10 & A0A2G5DW13 & Uncharacterized protein & 0.04 & 0.06 & 1.42 & 0.01 & redox \\
\hline 11 & A0A067KC46 & $\begin{array}{l}\text { Ribulose bisphosphate carboxylase } \\
\text { small chain }\end{array}$ & 0.06 & 0.09 & 1.41 & 0.02 & PS \\
\hline 12 & W9QII5 & Peroxiredoxin Q & 0.03 & 0.04 & 1.41 & 0.02 & redox \\
\hline 13 & A0A061EH79 & $\begin{array}{l}\text { Ribulose bisphosphate carboxylase } \\
\text { small chain }\end{array}$ & 0.05 & 0.07 & 1.41 & 0.00 & PS \\
\hline
\end{tabular}

${ }^{a}$ Protein ID, according to UniProtKB/Swiss-Prot database. ${ }^{b}$ Function, protein function categorized using MapMan bin codes. FC, fold change; PS, photosynthesis.

Chlorophyll biosynthetic enzymes glutamyl-tRNA reductase, Mg-protoporphyrin IX monomethylester cyclase, and plastidic 2-Cys PRXs are direct substrates of NTRC in Arabidopsis [44]. As a result, NTRC protects the formation of chlorophyll in Arabidopsis [45]. The NTRC, together with 2-Cys PRXs, forms a two component peroxide detoxifying system that acts as a reductant under stress conditions [44]. Overexpression of NTRC raises the $\mathrm{CO}_{2}$ fixation rate and lowers non-photochemical quenching by enhancing the activation of TRX-regulated enzymes and chloroplast ATP synthase in the Calvin cycle [46]. In this study, the amounts of total chlorophyll, chlorophyll a, and chlorophyll b 
were increased in VC plants compared with VV and control plants (Figure 6). The amount of 2-Cys peroxiredoxin was decreased in VV plants in response to HUV-B+D (Table S6), however, it was increased in VC plants compared with VV plants after HUV-B+D (Table 1). Furthermore, chloroplast ATP synthase was increased in VC plants compared with VV and control plants at the starting point and were increased more significantly in VC plants than in VV and control plants following HUV-B+D (Figure 8). The intercellular $\mathrm{CO}_{2}$ was significantly lower in VC than VV and control (Figure 7) which illustrated the silencing of CtPPO increased the utilization of carbon resource. These results help to increase understanding that CtPPO might influence the carbon fixation by regulating NTRC system.

\subsection{Silencing of PPO Enhanced the glycolysis in C. terniflora}

Glycolysis is a central metabolic pathway in plants that oxidizes hexoses to provide ATP, reduces power and pyruvate, and produces precursors for anabolism [47]. Studies have proved that the increase of PGK, and BPGM in Arabidopsis thaliana provide energy supply by ATP production [48,49]. Arabidopsis double mutants lacking BPGM enzyme activity exhibited defects in blue light, low $\mathrm{CO}_{2}$, and abscisic acid-regulated stomatal movements [49], which are responsible for all gaseous diffusion and can control photosynthetic $\mathrm{CO}_{2}$ uptake to influence photosynthesis [50]. The increased glycolytic proteins in root of oat enhanced ATP production and promoted adaptation to anaerobic conditions [51]. It has been suggested that the stomatal red-light response signal may be provided by the redox state of photosynthetic electron transport chain components, such as the redox state of plastoquinone and production of ATP [52]

In our study, the increases in GPUT, FBA, GAPDH, PGK, Enolase, and PEPC in CtPPO-silenced plants demonstrated the activation of glycolysis, which could provide more ATP for energy metabolism in C. terniflora. Further analysis also proved the enhanced stomatal conductance by the silencing of CtPPO in VC (Figure 7). The interaction of glyceraldehyde-3-phosphate dehydrogenase and phospholipase $\mathrm{D}$ might provide a direct connection between signal transduction, energy metabolism, and growth control in plant response to stress conditions [53]. Yasmeen's study suggest that $\mathrm{Cu}$ nanoparticles might enhance the tolerance of wheat to drought and salinity by increasing the glycolysis related protein abundance [54]. These results indicate the decrease in CtPPO activity in C. terniflora might elevate its stress tolerance by activating glycolysis metabolism.

\subsection{Artificial Interference with PPO Activity Has Potential Applications in Agricultural Production}

PPOs catalyze the oxidation of phenols to quinones that subsequently react with amino acids or proteins to form brown and black pigments, greatly reducing the appearance of quality of wheat products [55]. The role of plant PPO in postharvest browning has been the primary focus of research [56]. Although there is no evidence that high PPO activity is associated with depressed nutritional value, the darkened color still negatively affects consumer choice [57]. Studies on wheat concluded that the development of wheat cultivars with low grain PPO activity is one of the main objectives in wheat breeding programs [58]. Photosynthesis is the major trait for any further increase in the yield potential of crops [59]. Various genetic engineering approaches for enhancing C3 plant photosynthesis have been consistently proposed over the past years to improve the crop productivity [60-62]. Our study clearly suggests the potential for suppression of PPO activity on photosynthesis in C. terniflora, which indicates the feasibility of artificially mediating photosynthesis through the control of PPO gene expression. Nevertheless, it is undeniable that PPO has positive effects on plant defense in response to abiotic or biotic stresses as many PPO genes have been shown to be upregulated by wounding, pathogens, and hormones [63]. However, latent PPO enzymes can be activated by interactions with their substrates [64], occurring in great measure when plants are under stress. All in all, our current work provides a prospective approach for increasing crop yield in agricultural production. 


\section{Material and Methods}

\subsection{Plant Materials and Growth Conditions}

C. terniflora DC. seeds sprouted in incubators and the sprouts were sown into seedbeds. The seedlings were then transplanted into pots and placed in a greenhouse, which was controlled at $28-30{ }^{\circ} \mathrm{C}, 70-80 \%$ relative humidity, and $160 \mu \mathrm{mol} \mathrm{m}{ }^{-2} \mathrm{~s}^{-1}$ of white light irradiance. In the garden, conditions ranging from the soil to microclimate were equivalent among all plant samples. After six weeks, the plants were used for experiments [28].

\subsection{High Level UVB and Dark Treatment}

For HUV-B+D, 6-week-old plants were exposed to $104.4 \mathrm{~kJ} \mathrm{~m}^{-2} \mathrm{~d}^{-1}$ of UV-B irradiation at conditions of $25-30{ }^{\circ} \mathrm{C}$ and $80 \%$ relative humidity in a cabinet. Plants before irradiated were regarded as starting point samples. Intensity of UV-B irradiation was determined by a UV Light Meter (Beijing Normal University, Beijing, China). After irradiated by HUV-B for $5 \mathrm{~h}$, plants were incubated in dark for $48 \mathrm{~h}$. Leaves in the basal 10 to $60 \mathrm{~cm}$ of each experimental plant were collected as simples for further proteomic analyses. Five leaves were collected for each replicate and 3 independent biological replicates were assessed [28].

\subsection{RNA Extraction and Cloning of CtPPO Gene}

An RNeasy Plant Mini kit (Qiagen, Hilden, Germany) was used to obtain total RNA. Quantity and quality of obtained RNA were determined using an Agilent 2100 Bioanalyzer (Agilent Technologies, Palo Alto, CA, USA). The extracted total RNA was used as template to synthesize first-strand complementary DNA (cDNA) using an Oligo (dT) and OneScript ${ }^{\mathrm{TM}}$ Reverse Transcriptase OneScrpt ${ }^{\mathrm{TM}}$ cDNA Synthesis Kit (Applied Biological Materials Inc., Vancouver, BC, Canada). The first-strand cDNA was utilized as template for PCR using the primers listed in Table S5, which was designed based on the single EST sequence of a suspected CtPPO gene in the transcriptome of $C$. terniflora and amplification was performed as described [28]. The amplified PCR fragments, which were approximately 264 $\mathrm{bp}$ in length, were isolated, inserted into the $\mathrm{pMD}^{\mathrm{TM}} 18-\mathrm{T}$ Vector $\left(\mathrm{pMD}^{\mathrm{TM}} 18-\mathrm{T}\right.$ Vector Cloning Kit, Takara, Kyoto, Japan), and sequenced. The complete coding sequence of CtPPO was obtained using 5'and 3'-rapid amplification of cDNA ends (RACE) with internal specific primers (Table S3) using the SMARTer RACE cDNA Amplification Kit (Takara) according to the manufacturer's instructions.

The downstream sequence of CtPPO was obtained using a PCR-based genome walking approach with the Genome Walking Kit (Takara). Three designed primers (gene specific primer (GSP); Table S2) and 4 internal short degenerate arbitrarily primed (AP) primers included in the kit (AP1, AP2, AP3, and AP4) were used to perform genome-walking PCR. The PCR conditions and designed primer Tm were based on the manufacturer's instructions. Three-step nested PCR was performed to increase specificity. The nested PCR products were excised, purified, and sequenced.

\subsection{Construction of CtPPO Virus-Derived Vectors}

A 439-bp fragment of the obtained CtPPO gene was amplified using Permix TaqTM (Ex TaqTM Version 2.0 plus dry; Takara) and inserted into a $\mathrm{pMD}^{\mathrm{TM}} 18-\mathrm{T}$ vector $\left(\mathrm{pMD}^{\mathrm{TM}} 18-\mathrm{T}\right.$ Vector Cloning Kit, Takara) using primers TXPPO-F and TXPPO-R (Table S4) containing XbaI and BamHI restriction enzyme sites. The CtPPO sequence was harvested from the $\mathrm{pMD}^{\mathrm{TM}} 18-\mathrm{T}$ vector using the EcoRI restriction enzyme and inserted into the EcoRI site between the CaMV $35 S$ promoter $(2 \times 35 S)$ and NOS terminator of the pTRV2 vector. The orientation of the plasmid with pTRV2-CtPPO (Figure S1) was verified by sequencing. Assembly of the pTRV vector was performed as described [65]. The plasmids were sequenced to verify correct insertion of the fragment and transformed into Agrobacterium tumefaciens GV3101. 


\subsection{Virus-Induced Gene Silencing}

VIGS was performed according to the method described by Salim et al. [66]. The GV3101 strains of $A$. tumefaciens carrying pTRV1, pTRV2, and pTRV2-PPO were stored at $-80^{\circ} \mathrm{C}$. Agrobacteria were cultured in $300 \mathrm{~mL}$ of Luria-Bertani liquid medium containing $10 \mathrm{mM}$ 2-(N-morpholino) ethanesulfonic acid (MES), $50 \mu \mathrm{g} \mathrm{mL}^{-1}$ kanamycin, and $20 \mu \mathrm{M}$ acetosyringone. Then the cultures were centrifuged at the speed of $5000 \times g$ for $10 \mathrm{~min}$ and the resulting bacterial pellets were resuspended in $5 \mathrm{~mL}$ infiltration buffer containing $10 \mathrm{mM} \mathrm{MgCl}_{2}, 10 \mathrm{mM}$ MES and $200 \mu \mathrm{M}$ acetosyringone, and incubated at $28^{\circ} \mathrm{C}$ with shaking for $3 \mathrm{~h}$. The mixed suspensions were used for surface infiltration of three-week-old Nicotiana benthamiana seedlings using a needleless syringe and 4-6 leaves were infected. The PDS (phytoene desaturase) gene was used as a marker for the evaluation of the efficiency of VIGS in CtPPO genes silencing in N. benthamiana. The VIGS N. benthamiana plants were grown in a greenhouse and the TRV virus was detected by PCR to confirm infection of the $N$. benthamiana leaves. The successfully infected $N$. benthamiana leaves were used for the abrasion inoculation of $C$. terniflora leaves as described below.

Virus-infected $N$. benthamiana leaves $(1 \mathrm{~g})$ were ground with $2 \mathrm{~mL}$ of $10 \mathrm{mM}$ potassium phosphate buffer ( $\mathrm{pH} 7$ ) containing 1-2\% w/v Celite 545 AW abrasive (Sigma-Aldrich, Milwaukee, WI, USA) using a mortar and pestle. The resulting homogenate was used for inoculation by the abrasion method on all tender leaves of 3-week-old C. terniflora plants. Two groups of plants, one containing the pTRV virus vector and the other the PTRV-PPO virus vector, were prepared and each was inoculated, where six plants were used as biological replicates.

\subsection{Protein Extraction, Enrichment, and Digestion for Proteomics Analysis}

The tissues were ground in liquid nitrogen. For protein extraction, the phenol extraction method was performed according to a previously published protocol [67]. Briefly, $6 \mathrm{~g}$ of frozen powder was suspended in $15 \mathrm{~mL}$ of homogenization medium containing $50 \%(v / v)$ phenol, $100 \mathrm{mM} \mathrm{KCl}, 50 \mathrm{mM}$ EDTA, $0.2 \%(v / v)$ 2-mercaptoethanol, $1 \mathrm{mM}$ PMSF, $700 \mathrm{mM}$ sucrose, and $500 \mathrm{mM}$ Tris- $\mathrm{HCl}$ at $\mathrm{pH}$ 7.5 , shaken at $37^{\circ} \mathrm{C}$ for $15 \mathrm{~min}$, and then centrifuged at the speed of $2500 \times \mathrm{g}$ at $4{ }^{\circ} \mathrm{C}$ for $20 \mathrm{~min}$. Four volumes of precipitation solution $(0.1 \mathrm{M}$ ammonium acetate in $100 \%$ methanol) were added in to the phenolic phase collected to precipitate the proteins. The precipitate was collected by centrifugation for $10 \mathrm{~min}$ at the speed of $2500 \times \mathrm{g}$. The supernatant was discarded and washed with precipitation solution. Precipitation was allowed to occur at $-20{ }^{\circ} \mathrm{C}$ for $3 \mathrm{~h}$ and the precipitate was obtained by centrifugation, which was repeated twice. The collected proteins were dissolved in $0.5 \mathrm{~mL}$ of $50 \mathrm{mM}$ ammonium bicarbonate (ABC). Protein concentrations were determined using the Bradford assay with bovine serum albumin as the standard.

The protein $(100 \mu \mathrm{g})$ and an additional $50 \mathrm{mM} \mathrm{ABC}$ were transferred into a new tube to create a final volume of $100 \mu \mathrm{L}$. The protein was reduced with $10 \mathrm{mM}$ dithiothreitol for $1 \mathrm{~h}$ at $55^{\circ} \mathrm{C}$ and alkylated with $50 \mathrm{mM}$ iodoacetamide at $37^{\circ} \mathrm{C}$ for $30 \mathrm{~min}$ in darkness, then digested with sequence-grade modified trypsin (Promega, Fitchburg, WI, USA). Trypsin and $1 \%$ lysyl endopeptidase were added to the protein and then the solutions were incubated in a water bath at $37^{\circ} \mathrm{C}$ for $4 \mathrm{~h}$ and another $1 \%$ enzyme was added. The solutions were incubated at $37^{\circ} \mathrm{C}$ for $12 \mathrm{~h}$, centrifuged at $10,000 \times g$, and then dried in a vacuum. Trypsinized peptides in $200 \mu \mathrm{L}$ of $0.1 \%$ trifluoroacetic acid (TFA) and $0.5 \%$ acetonitrile were loaded onto activated and balanced C18 SPE columns (Sep-Pak C18; Waters, Milford, MA, USA). After washing the column with $200 \mu \mathrm{L}$ of $0.1 \%$ TFA and $0.5 \%$ acetonitrile, $300 \mu \mathrm{L}$ of $0.1 \%$ TFA and $60 \%$ acetonitrile were added and then the elution solution was collected and dried in a vacuum. Obtained supernatant was collected for subsequent analysis.

\subsection{Nano-HPLC-MS/MS Analysis}

The peptides were resuspended in $100 \mu \mathrm{L}$ of solvent $\mathrm{A}$ (water with $0.1 \%$ formic acid; B: ACN with $0.1 \%$ formic acid), separated by nano-UPLC, and analyzed by online electrospray tandem MS, which were performed on a Nano Aquity UPLC system (Waters Corporation, Milford, MA, USA) connected 
to a quadrupole-Orbitrap mass spectrometer (Q-Exactive; Thermo Fisher Scientific, Bremen, Germany) equipped with an online nano-electrospray ion source. Peptide samples $(2 \mu \mathrm{L})$ were loaded onto the trap column (Thermo Scientific Acclaim PepMap C18, $100 \mu \mathrm{m} \times 2 \mathrm{~cm}$ ) with a flow of $10 \mu \mathrm{L} / \mathrm{min}$ for $3 \mathrm{~min}$ and subsequently separated on an analytical column (Acclaim PepMap C18, $75 \mu \mathrm{m} \times 25 \mathrm{~cm}$ ) with a linear gradient of 1 to $30 \%$ solvent B (acetonitrile with $0.1 \%$ formic acid) in $95 \mathrm{~min}$. The column was re-equilibrated at the initial conditions for $15 \mathrm{~min}$. The column flow rate was maintained at $300 \mathrm{~nL} / \mathrm{min}$. The electrospray voltage of $2.0 \mathrm{kV}$ versus the inlet of the mass spectrometer was used.

The Q-Exactive mass spectrometer was set at the data-dependent mode allowing the machine switch between MS and MS/MS acquisition automatically. Survey full-scan MS spectra $(m / z 350-1600)$ were acquired with a mass resolution of $70 \mathrm{~K}$ followed by fifteen sequential high-energy collisional dissociation MS/MS scans with a resolution of $17.5 \mathrm{~K}$. One microscan was recorded using a dynamic exclusion of $30 \mathrm{~s}$ in all cases. The MS/MS fixed first mass was set at 100.

\subsection{Protein Identification Based on Mass Spectrometry Data}

Tandem mass spectra were extracted by Proteome Discoverer software (Thermo Fisher Scientific, version 1.4.0.288, Bremen, Germany). Charge state deconvolution and deisotoping were not performed. All MS/MS samples were analyzed using Mascot (Matrix Science, London, UK; version 2.3). Mascot was set up to search the Uniprot database (Taxonomy: Viridiplantae, 5716577 entries, https: / /www. uniprot.org/) assuming the digestion enzyme trypsin. Mascot was searched with a fragment ion mass tolerance of $0.050 \mathrm{Da}$ and a parent ion tolerance of $10.0 \mathrm{PPM}$. Carbamidomethyl of cysteine was specified in Mascot as fixed modifications. Oxidation of methionine was specified in Mascot as a variable modification. Minimum peptide length was set to six amino acids the false discovery rate was set to 0.01 for peptide identifications. Identified peptides shared between two proteins were combined and reported as one protein group. The minimum requirement for the identification of a protein was a minimum of 2 matched peptides and a $p$-value $<0.05$. Spectral counting was used to estimate relative protein abundance [68]. The mass spectrometry proteomics data have been deposited to the ProteomeXchange Consortium via the PRIDE [69] partner repository with the dataset identifier PXD011439.

\subsection{Functional Annotation}

Protein functions were categorized using MapMan bin codes (available online: http:/ / mapman. gabipd.org/) [70]. Annotations were transferred to the Arabidopsis genome with consideration for orthologous genes to predict functions of identified proteins from C. terniflora. Pathway mapping of identified proteins was performed using the Kyoto Encyclopedia of Genes and Genomes (KEGG) database (available online: http:/ / www.genome.jp/kegg/) [71].

\subsection{Cluster Analysis of Protein Abundance}

Protein abundance ratios were used for cluster analysis, performed on Cluster 3.0 software version 3.0 (available online: http:/ / bonsai.hgc.jp/ \{\}mdehoon/software/cluster/) [72].

\subsection{Phylogenetic Analysis}

The amino acid sequences of CtPPO were aligned using CLUSTALW (available online: http:/ /www.clustal.org/) [73] and a neighbor-joining phylogenetic tree was computed with MEGA6 (available online: http:/ /www.clustal.org/) using 1000 bootstrapped replicates [74].

\subsection{2. $q R T-P C R$}

Total RNA of leaves was extracted using an RNA isolation kit (Huayueyang, Beijing, China) and served as the template for reverse transcription using $5 \times$ All-In-One RT MasterMix with an AccuRT Genomic DNA Removal Kit (Applied Biological Materials, Richmond, BC, Canada) to obtain 
cDNA. Next, qRT-PCR was performed on a Bio-Rad IQ2 Multicolor Real-Time PCR Detection System (Bio-Rad, Hercules, CA, USA) with EvaGreen $2 \times$ qPCR Master Mix-iCycler (Applied Biological Materials) as the fluorescent dye. GAPDH, a housekeeping gene, was used as a standard for relative quantification of target genes. The gene-specific primers are listed in Additional file 1: Table S1. Three biological replicates were assessed and the relative expression levels were calculated using the $2^{-\Delta \Delta C t}$ method [26].

\subsection{PPO Enzymatic Activity}

Enzymatic activity of PPO was assayed as described by Marko et al. [75]. Frozen leaf $(0.5 \mathrm{~g})$ was homogenized with $1 \mathrm{~mL}$ of $50 \mathrm{mM}$ sodium phosphate buffer ( $\mathrm{pH} 7.5)$ containing $1 \%(w / v)$ polyvinyl polypyrrolidone and $0.1 \mathrm{mM}$ EDTA using a pre-chilled mortar and pestle. After extraction in an end-over-end shaker at $4{ }^{\circ} \mathrm{C}$ for 20 mins, the mixture was centrifuged at $16000 \times g$ for $20 \mathrm{~min}$ at $4{ }^{\circ} \mathrm{C}$ and the resulting supernatant was used in enzyme extraction.

Then, $800 \mu \mathrm{L}$ of $0.1 \mathrm{M}$ sodium phosphate buffer ( $\mathrm{pH}$ 6.0) containing $50 \mathrm{mM}(+)$-catechin (Carl Roth, Karlsruhe, Germany) was mixed with $150 \mu \mathrm{L}$ of enzyme extraction sample and incubated for $15 \mathrm{~min}$ at $37^{\circ} \mathrm{C}$. The reaction was terminated by adding $150 \mu \mathrm{L}$ of $6 \mathrm{~N} \mathrm{HCl}$ and the absorbance at $420 \mathrm{~nm}$ was recorded and used in further calculations. Protein concentration was determined according to Bradford using bovine serum albumin as the reference protein. Specific PPO activity was calculated as units (U) per mg sample protein with $1 \mathrm{U}$ corresponding to an absorbance change of $0.01 / \mathrm{min}$. Since levels of PPO activity in the control plants were somewhat variable between independent experiments, data were normalized to the specific PPO activity in leaves of healthy wild-type controls and the results are shown as fold induction (with 1 corresponding to a specific activity of 3.2 to $23 \mathrm{U} / \mathrm{mg}$ ).

\subsection{Analysis of Photosynthesis Characteristics}

An Li-6400 Portable Photosynthesis System (Li-Cor, Lincoln, NE, USA) equipped with a red/blue LED light source were used to measure the photosynthesis characteristics of the leaves, and was operated using air from a large volume with a stable $\mathrm{CO}_{2}$ partial pressure. All measurements were carried out at a photon flux density of $500 \mu \mathrm{mol} \mathrm{m}{ }^{-2} \mathrm{~s}^{-1}$ at $28{ }^{\circ} \mathrm{C}$ and made after stable reading was achieved. The photosynthesis rate $\left(\mu \mathrm{mol} \mathrm{m}{ }^{-2} \mathrm{~s}^{-1}\right)$, stomatal conductance $\left(\mathrm{mol} \mathrm{m}^{-2} \mathrm{~s}^{-1}\right)$, and transpiration rate $\left(\mathrm{mmol} \mathrm{m}^{-2} \mathrm{~s}^{-1}\right)$ of each leaf were recorded. Each experiment was repeated for different plants three times and three independent biological replicates were assessed.

\subsection{Analysis of Chlorophyll Content}

C. terniflora leaves $(0.2 \mathrm{~g})$ were cut up and blended with $10 \mathrm{~mL}$ of $95 \%$ alcohol in a tube. The tube was covered and the leaves soaked in the dark until they had turned completely white. The absorbances of the extracting solutions were measured at wavelengths of 665,649 , and $470 \mathrm{~nm}$ separately. The chlorophyll content was calculated using Chlorophyll a $(\mathrm{Ca})=13.95 \mathrm{D}_{665}-6.88$ $\mathrm{D}_{649}$, Chlorophyll b $(\mathrm{Cb})=24.96 \mathrm{D}_{649}-7.32 \mathrm{D}_{665}$, Carotenoid $=\left(1000 \mathrm{D}_{470}-2.05 \mathrm{Ca}-114 \mathrm{Cb}\right) / 245$, and Total chlorophyll $=\mathrm{Ca}+\mathrm{Cb}$.

\subsection{Statistical Analysis}

Statistical significance comparing two groups was determined using Student's $t$-test and multiple groups using one-way ANOVA followed by Tukey's test. Statistical evaluation was performed on SPSS statistical software version 22.0 (IBM, Armonk, NY, USA). A $p$-value $<0.05$ was considered statistically significant.

\subsection{Accession Codes}

The nucleotide sequence of CtPPO has been deposited in the GenBank ${ }^{\mathrm{TM}}$ database under the accession number MK070494. 


\section{Conclusions}

PPO is an oxidoreductase that plays a crucial role in the biosynthesis of secondary metabolites. C. terniflora is a Chinese folk medical resource with potential pharmaceutical value for the treatment of various diseases [21]. High-intensity UV-B and dark incubation (HUV-B+D), which are helpful stressors for medicinal plants [28]. Omics technologies were used on C. terniflora to prospectively understand the inherent mechanism underlying its medicinal quality $[24,26]$. To clarify the in vivo physiological functions of PPO, we performed a comparative proteomic analysis on the leaves of $C$. terniflora with down-regulated PPO activity by VIGS. The main findings are as follows: (i) The differentially expressed proteins were mainly functioned in photosynthesis, glycolysis and redox in the VC plants; (ii) the differentially expressed proteins related to photosynthesis were mainly involved in light reaction and Calvin cycle; (iii) the expression level of adenosine triphosphate (ATP) synthase, the content of chlorophyll, and the photosynthesis rate were increased in VC plants compared to VV plants pre- and post HUV-B+D. Taken together, these results indicate that the silence of PPO can activate the glycolysis process, regulate Calvin cycle and provide ATP for energy metabolism to elevate the plant photosynthesis. And this study provides a prospective approach for increasing crop yield in agricultural production.

Supplementary Materials: The following are available online at http:/ / www.mdpi.com/1422-0067/19/12/3897/ s1.

Author Contributions: Conceptualization, X.C., B.Y. and J.T.; methodology, X.C. and B.Y.; software, W.H. and T.W.; validation, L.Y. and S.L.; formal analysis, W.H.; investigation, X.C. and Y.L.; resources, B.Y.; data curation, T.W.; writing — original draft preparation, X.C. and B.Y.; writing—review and editing, X.C., B.Y. and Z.Z.; visualization, Y.L.; supervision, B.Y.; project administration, X.C.; funding acquisition, B.Y and J.T.

Funding: This research was funded by National Science and Technology Major Project of China, grant number No. 2017ZX09301007; National Natural Science Foundation of China, grant number No. 81703634; and Zhejiang Provincial Science and Technology Planning Project, grant number No. 2016C04005.

Conflicts of Interest: The authors declare no conflict of interest.

$\begin{array}{ll}\text { Abbreviations } \\ \text { 3-PGA } & \text { 3-Phosphoglycerate } \\ \text { ABA } & \text { Abscisic acid } \\ \text { ABC } & \text { Ammonium bicarbonate } \\ \text { ACN } & \text { Acetonitrile } \\ \text { ATP } & \text { Adenosine triphosphate } \\ \text { BPGM } & \text { Phosphoglycerate mutase } \\ \text { C. terniflora } & \text { Clematis terniflora } \\ \text { CtPPO } & \text { PPO gene in C. terniflora } \\ \text { DEPs } & \text { Differentially expressed proteins } \\ \text { ETC } & \text { Electron transport chain } \\ \text { FBA } & \text { Fructose-1,6-bisphosphate aldolase } \\ \text { FBPase } & \text { Fructose-1,6-bisphosphatase } \\ \text { Fd } & \text { Ferredoxin } \\ \text { FTR } & \text { Fd-TRX reductase } \\ \text { GAP } & \text { Glyceraldehyde 3-phosphate } \\ \text { GAPDH } & \text { Glyceraldehyde-3-phosphate dehydrogenase } \\ \text { GPI } & \text { Glucose-6-phosphate isomerase } \\ \text { GPUT } & \text { UTP-glucose-1-phosphate uridylytransferase } \\ \text { HCD } & \text { High energy collisional dissociation } \\ \text { HUV-B+D } & \text { High level of UV-B and dark } \\ \text { KEGG } & \text { Kyoto Encyclopedia of Genes and Genomes } \\ \text { MES } & \text { 2-(N-morpholino) ethanesulfonic acid } \\ \text { NTRC } & \text { NADPH-dependent TRX reductase } \\ & \end{array}$




$\begin{array}{ll}\text { ORF } & \text { Open reading frame } \\ \text { PDS } & \text { Phytoene desaturase } \\ \text { PEP } & \text { Phosphoenolpyruvate } \\ \text { PEPC } & \text { Phosphoenolpyruvate carboxylase } \\ \text { PGK } & \text { Phosphoglycerate kinase } \\ \text { PPO } & \text { Polyphenol oxidase } \\ \text { PRK } & \text { Phosphoribulokinase } \\ \text { PS I } & \text { Photosystem I } \\ \text { PS II } & \text { Photosystem II } \\ \text { PS } & \text { Photosystem } \\ \text { RACE } & \text { 5' Rapid amplification of cDNA ends } \\ \text { Rubisco } & \text { Ribulose-1,5-bisphosphate carboxylase/oxygenase } \\ \text { RuBP } & \text { Ribulose 1,5-bisphosphate } \\ \text { SBPase } & \text { Sedoheptulose-1,7-bisphosphatase } \\ \text { TCA } & \text { Tricarboxylic acid } \\ \text { TFA } & \text { Trifluoroacetic acid } \\ \text { TK } & \text { Transketolase } \\ \text { TRV } & \text { Tobacco rattle virus } \\ \text { TRX } & \text { Thioredoxin } \\ \text { UTR } & \text { Untranslated Region } \\ \text { VIGS } & \text { Virus-induced gene silencing } \\ \text { VC } & \text { VIGS-CtPPO } \\ \text { VV } & \text { VIGS-vector } \\ \end{array}$

\section{References}

1. Hart, E.H.; Onime, L.A.; Davies, T.E.; Morphew, R.M.; Kingston-Smith, A.H. The effects of PPO activity on the proteome of ingested red clover and implications for improving the nutrition of grazing cattle. J. Proteom. 2016, 141, 67-76. [CrossRef]

2. Kroll, J.; Rawel, H.M. Reactions of Plant Phenols with Myoglobin: Influence of Chemical Structure of the Phenolic Compounds. J. Food Sci. 2010, 66, 48-58. [CrossRef]

3. Nakayama, T.; Yonekura-Sakakibara, K.; Sato, T.; Kikuchi, S.; Fukui, Y.; Fukuchi-Mizutani, M.; Ueda, T.; Nakao, M.; Tanaka, Y.; Kusumi, T.; et al. Aureusidin synthase: A polyphenol oxidase homolog responsible for flower coloration. Science 2000, 290, 1163-1166. [CrossRef] [PubMed]

4. Gandia-Herrero, F.; Escribano, J.; Garcia-Carmona, F. Characterization of the monophenolase activity of tyrosinase on betaxanthins: The tyramine-betaxanthin/dopamine-betaxanthin pair. Planta 2005, 222, 307-318. [CrossRef] [PubMed]

5. Li, L.; Steffens, J.C. Overexpression of polyphenol oxidase in transgenic tomato plants results in enhanced bacterial disease resistance. Planta 2002, 215, 239-247. [CrossRef]

6. Thipyapong, P.; Mahanil, S.; Bhonwong, A.; Attajarusit, J.; Stout, M.J.; Steffens, J.C. Increasing Resistance of Tomato to Lepidopteran Insects by Overexpression of Polyphenol Oxidase. Acta Hortic. 2006, 22, 29-38. [CrossRef]

7. Jia, H.; Zhao, P.; Wang, B.; Tariq, P.; Zhao, F.; Zhao, M.; Wang, Q.; Yang, T.; Fang, J. Overexpression of Polyphenol Oxidase Gene in Strawberry Fruit Delays the Fungus Infection Process. Plant Mol. Biol. Report. 2016, 34, 592-606. [CrossRef]

8. Sofo, A.; Dichio, B.; Xiloyannis, C.; Masia, A. Antioxidant defences in olive trees during drought stress: Changes in activity of some antioxidant enzymes. Funct. Plant Biol. 2005, 32, 351-364. [CrossRef]

9. Araji, S.; Grammer, T.A.; Gertzen, R.; Anderson, S.D.; Mikulic-Petkovsek, M.; Veberic, R.; Phu, M.L.; Solar, A.; Leslie, C.A.; Dandekar, A.M.; et al. Novel roles for the polyphenol oxidase enzyme in secondary metabolism and the regulation of cell death in walnut. Plant Physiol. 2014, 164, 1191-1203. [CrossRef]

10. Murniati, A.; Buchari, B.; Gandasasmita, S.; Nurachman, Z.; Nurhanifah, N. Characterization of Polyphenol Oxidase Application as Phenol Removal in Extracts of Rejected White Oyster Mushrooms (Pleurotus ostreatus). Orient. J. Chem. 2018, 34, 1457-1468. [CrossRef] 
11. Sommer, A.; Ne'Eman, E.; Koussevitzky, S.; Hunt, M.D.; Steffens, J.C.; Mayer, A.M.; Harel, E. The Inhibition by Cu2+ of the Import of Polyphenol Oxidase into Chloroplasts. Photosynth. Light Biosph. 1995, 3, 827-830.

12. Koussevitzky, S.; Ne'Eman, E.; Harel, E. Import of polyphenol oxidase by chloroplasts is enhanced by methyl jasmonate. Planta 2004, 219, 412-419. [CrossRef] [PubMed]

13. Mayer, A.M. Polyphenol oxidases in plants and fungi: Going places? A review. Phytochemistry 2006, 67, 2318-2331. [CrossRef] [PubMed]

14. Velásquez, A.C.; Chakravarthy, S.; Martin, G.B. Virus-induced gene silencing (VIGS) in Nicotiana benthamiana and tomato. J. Vis. Exp. 2009, 28, 1292.

15. Lee, W.S.; Rudd, J.J.; Kanyuka, K. Virus induced gene silencing (VIGS) for functional analysis of wheat genes involved in Zymoseptoria tritici susceptibility and resistance. Fungal Genet. Biol. 2015, 79, 84-88. [CrossRef]

16. Zhao, D.; Zhao, J.R.; Huang, X.; Li, N.; Liu, Y.; Huang, Z.J.; Zhang, Z.Y. Functional Analysis of TNBL1 Gene in Wheat Defense Response to Barley yellow dwarf virus Using BSMV-VIGS Technique. Acta Agron. Sin. 2011, 37, 2106-2110. [CrossRef]

17. Groszyk, J.; Kowalczyk, M.; Yanushevska, Y.; Stochmal, A.; Rakoczy-Trojanowska, M.; Orczyk, W. Identification and VIGS-based characterization of Bx1 ortholog in rye (Secale cereale L.). PLoS ONE 2017, 12, e0171506. [CrossRef] [PubMed]

18. Gao, W.; Long, L.; Zhu, L.F.; Rong, Y.M.; Lu, X.H.; Sun, M.Y.; Zhang, L.; Tian, J.K. Proteomic and Virus-induced Gene Silencing (VIGS) Analyses Reveal That Gossypol, Brassinosteroids, and Jasmonic acid Contribute to the Resistance of Cotton to Verticillium dahliae. Mol. Cell. Proteom. 2013, 12, 3690-3703. [CrossRef] [PubMed]

19. Zhao, X.D.; Yuan, X.Y.; Chen, S.; Meng, L.; Fu, D. Role of the tomato TAGL1 gene in regulating fruit metabolites elucidated using RNA sequence and metabolomics analyses. PLoS ONE 2018, 13, e0199083. [CrossRef] [PubMed]

20. Zhou, B.J.; Zeng, L. Elucidating the role of highly homologous Nicotiana benthamiana ubiquitin E2 gene family members in plant immunity through an improved virus-induced gene silencing approach. Plant Methods 2017, 13, 59. [CrossRef]

21. Chen, R.Z.; Cui, L.; Guo, Y.J.; Rong, Y.M.; Lu, X.H.; Sun, M.Y.; Zhang, L.; Tian, J.K. In vivo study of four preparative extracts of Clematis terniflora, DC. for antinociceptive activity and anti-inflammatory activity in rat model of carrageenan-induced chronic non-bacterial prostatitis. J. Ethnopharmacol. 2011, 134, 1018-1023. [CrossRef] [PubMed]

22. Zhang, L.J.; Huang, H.T.; Huang, S.Y.; Lin, Z.H.; Shen, C.C.; Tsai, W.J.; Kuo, Y.H. Antioxidant and Anti-Inflammatory Phenolic Glycosides from Clematis tashiroi. J. Nat. Prod. 2015, 78, 1586-1592. [CrossRef] [PubMed]

23. Wang, L.L.; Huang, Y.H.; Yan, C.Y.; Wei, X.D.; Hou, J.Q.; Pu, J.X.; Lv, J.X. N-acetylcysteine Ameliorates Prostatitis via miR-141 Regulating Keap1/Nrf2 Signaling. Inflammation 2016, 39, 938-947. [CrossRef] [PubMed]

24. Yang, B.X.; Wang, X.; Gao, C.X.; Chen, M.; Guan, Q.J.; Tian, J.K.; Komatsu, S. Proteomic and Metabolomic Analyses of Leaf from Clematis terniflora DC. Exposed to High-Level Ultraviolet-B Irradiation with Dark Treatment. J. Proteome Res. 2015, 15, 2643-2657. [CrossRef] [PubMed]

25. Liu, X.B.; Yang, B.X.; Zhang, L.; Lu, Y.Z.; Gong, M.H.; Tian, J.K. An in vivo, and in vitro, assessment of the anti-inflammatory, antinociceptive, and immunomodulatory activities of Clematis terniflora, DC. extract, participation of aurantiamide acetate. J. Ethnopharmacol. 2015, 169, 287-294. [CrossRef] [PubMed]

26. Gao, C.X.; Yang, B.X.; Zhang, D.D.; Chen, M.; Tian, J.K. Enhanced metabolic process to indole alkaloids in Clematis terniflora, DC. after exposure to high level of UV-B irradiation followed by the dark. BMC Plant Biol. 2016, 16, 231. [CrossRef]

27. Boeckx, T.; Winters, A.L.; Webb, K.J.; Kingston-Smith, A.H. Polyphenol oxidase in leaves: Is there any significance to the chloroplastic localization? J. Exp. Bot. 2015, 66, 3571-3579. [CrossRef]

28. Yang, B.X.; Guan, Q.J.; Tian, J.K.; Komatsu, S. Transcriptomic and proteomic analyses of leaves from Clematis terniflora, DC. under high level of ultraviolet-B irradiation followed by dark treatment. J. Proteom. 2016, 150, 323-340. [CrossRef]

29. Joliot, P.; Joliot, A. Cyclic electron flow in C3 plants. BBA Bioenerg. 2015, 1757, 362-368. [CrossRef]

30. Arnon, D.I.; Whatley, F.R.; Allen, M.B. Vitamin K as a cofactor of photosynthetic phosphorylation. BBA Biochim. Biophys. Acta 1955, 16, 607-608. [CrossRef] 
31. Grondelle, R.V.; Zuber, H. The light reactions of photosynthesis. Proc. Natl. Acad. Sci. USA 1971, 68, 2883-2892. [CrossRef]

32. Karlusich, J.J.P.; Carrillo, N. Evolution of the acceptor side of photosystem I: Ferredoxin, flavodoxin, and ferredoxin-NADP +, oxidoreductase. Photosynth. Res. 2017, 134, 235-250. [CrossRef] [PubMed]

33. Aliverti, A.; Pandini, V.; Pennati, A.; Rosa, M.; Zanetti, G. Structural and functional diversity of ferredoxin-NADP(+) reductases. Arch. Biochem. Biophys. 2008, 474, 283-291. [CrossRef] [PubMed]

34. Hisabori, T.; Sunamura, E.I.; Kim, Y.; Konno, H. The Chloroplast ATP Synthase Features the Characteristic Redox Regulation Machinery. Antioxid. Redox Signal. 2013, 19, 1846-1854. [CrossRef] [PubMed]

35. Kohzuma, K.; Bosco, C.D.; Meurer, J.; Kramer, D.M. Light- and Metabolism-related Regulation of the Chloroplast ATP Synthase Has Distinct Mechanisms and Functions. J. Biol. Chem. 2013, 288, 13156-13163. [CrossRef] [PubMed]

36. Tezara, W.; Mitchell, V.J.; Driscoll, S.D.; Lawlor, D.W. Water stress inhibits plant photosynthesis by decreasing coupling factor and ATP. Nature 1999, 401, 914-917. [CrossRef]

37. Shu, S.; Chen, L.; Lu, W.; Sun, J.; Guo, S.; Yuan, Y.; Li, J. Effects of exogenous spermidine on photosynthetic capacity and expression of Calvin cycle genes in salt-stressed cucumber seedlings. J. Plant Res. 2014, 127, 763-773. [CrossRef]

38. Hanke, G.; Mulo, P. Plant type ferredoxins and ferredoxin-dependent metabolism. Plant Cell Environ. 2013, 36, 1071-1084. [CrossRef]

39. Brandes, H.K.; Hartman, F.C.; Lu, T.Y.S.; Larimer, F.W. Efficient Expression of the Gene for Spinach Phosphoribulokinase in Pichia pastoris and Utilization of the Recombinant Enzyme to Explore the Role of Regulatory Cysteinyl Residues by Site-directed Mutagenesis. J. Biol. Chem. 1996, 271, 6490-6496. [CrossRef]

40. Nikkanen, L.; Rintamäki, E. Thioredoxin-dependent regulatory networks in chloroplasts under fluctuating light conditions. Philos. Trans. R Soc. Lond. 2014, 369, 20130224. [CrossRef]

41. Thormählen, I.; Meitzel, T.; Groysman, J.; Öchsner, A.B.; von Roepenach-Lahaye, E.; Naranjo, B.; Cejudo, F.J.; Geigenberger, P. Thioredoxin f1 and NADPH-Dependent Thioredoxin Reductase C Have Overlapping Functions in Regulating Photosynthetic Metabolism and Plant Growth in Response to Varying Light Conditions. Plant Physiol. 2015, 169, 1766-1786. [CrossRef] [PubMed]

42. Sommer, A.; Ne'Eman, E.; Steffens, J.C.; Mayer, A.M.; Harel, E. Import, targeting, and processing of a plant polyphenol oxidase. Plant Physiol. 1994, 105, 1301-1311. [CrossRef] [PubMed]

43. Qi, J.; Li, G.Q.; Dong, Z.; Zhou, W. Transformation of tobacco plants by Yali PPO-GFP fusion gene and observation of subcellular localization. Am. J. Transl. Res. 2016, 8, 698. [PubMed]

44. Richter, A.S.; Peter, E.; Rothbart, M.; Schlicke, H.; Toivola, J.; Rintamäki, E.; Grimm, B. Posttranslational influence of NADPH-dependent thioredoxin reductase $\mathrm{C}$ on enzymes in tetrapyrrole synthesis. Plant Physiol. 2013, 162, 63-73. [CrossRef] [PubMed]

45. Lepisto, A.; Kangasjarvi, S.; Luomala, E.M.; Brader, G.; Sipari, N.; Keränen, M.; Keinänen, M.; Rintamäki, E. Chloroplast NADPH-Thioredoxin Reductase Interacts with Photoperiodic Development in Arabidopsis. Plant Physiol. 2009, 149, 1261-1276. [CrossRef] [PubMed]

46. Nikkanen, L.; Toivola, J.; Rintamäki, E. Crosstalk between chloroplast thioredoxin systems in regulation of photosynthesis. Plant Cell Environ. 2016, 39, 1691-1705. [CrossRef] [PubMed]

47. Lunt, S.Y.; Vander Heiden, M.G. Aerobic glycolysis: Meeting the metabolic requirements of cell proliferation. Annu. Rev. Cell Dev. Biol. 2011, 27, 441-464. [CrossRef]

48. Rosa-Téllez, S.; Anoman, A.D.; Flores-Tornero, M.; Toujani, W.; Alseek, S.; Femie, A.R.; Nebauer, S.G.; Muñoz-Bertomeu, J.; Segura, J.; Ros, R. Phosphoglycerate Kinases Are Co-Regulated to Adjust Metabolism and to Optimize Growth. Plant Physiol. 2017, 176, 1182-1198. [CrossRef]

49. Zhao, Z.; Assmann, S.M. The glycolytic enzyme, phosphoglycerate mutase, has critical roles in stomatal movement, vegetative growth, and pollen production in Arabidopsis thaliana. J. Exp. Bot. 2011, 62, 5179-5189. [CrossRef]

50. Lawson, T.; Blatt, M.R. Stomatal size, speed, and responsiveness impact on photosynthesis and water use efficiency. Plant Physiol. 2014, 164, 1556-1570. [CrossRef]

51. Bai, J.; Liu, J.; Jiao, W.; Sa, R.; Zhang, N.; Jia, R. Proteomic analysis of salt-responsive proteins in oat roots (Avena sativa L.). J. Sci. Food Agric. 2016, 96, 3867-3875. [CrossRef] [PubMed] 
52. Azoulay-Shemer, T.; Palomares, A.; Bagheri, A.; Israelsson-Nordstrom, M.; Engineer, C.B.; Bargmann, B.O.; Stephan, A.B.; Schroeder, J.I. Guard cell photosynthesis is critical for stomatal turgor production, yet does not directly mediate $\mathrm{CO}_{2}$ - and ABA-induced stomatal closing. Plant J. 2015, 83, 567-581. [CrossRef]

53. Guo, L.; Devaiah, S.P.; Narasimhan, R.; Pan, X.; Zhang, Y.; Zhang, W.; Wang, X. Cytosolic glyceraldehyde-3-phosphate dehydrogenases interact with phospholipase D $\delta$ to transduce hydrogen peroxide signals in the Arabidopsis response to stress. Plant Cell 2012, 24, 2200-2212. [CrossRef] [PubMed]

54. Yasmeen, F.; Raja, N.I.; Razzaq, A.; Komatsu, S. Proteomic and physiological analyses of wheat seeds exposed to copper and iron nanoparticles. BBA Proteins Proteom. 2017, 1865, 28-42. [CrossRef] [PubMed]

55. Feillet, P.; Autran, J.C.; Icard-Vernière, C. Pasta brownness: An assessment. J. Cereal Sci. 2000, 32, $215-233$. [CrossRef]

56. Mesquita, V.L.V.; Queiroz, C. Enzymatic Browning Biochemistry of Foods; Elsevier Inc.: Amsterdam, The Netherlands, 2013.

57. Simeone, R.; Pasqualone, A.; Clodoveo, M.L.; Blanco, A. Genetic mapping of polyphenol oxidase in tetraploid wheat. Cell. Mol. Biol. Lett. 2002, 7, 763-769. [PubMed]

58. Sun, J.Z.; Zhao, J.T.; Liu, D.C.; Yang, W.L.; Luo, G.B.; Zhang, L.Y.; Zhang, X.Q.; Zhang, A.M. Modification to the Test Method of Polyphenol Oxidase(PPO) Activity in Wheat Seeds and Its Usage in Breeding Programs. J. Triticeae Crops 2012, 3, 13.

59. Long, S.P.; Zhu, X.; Naidu, S.L.; Ort, D.R. Can improvement in photosynthesis increase crop yields? Plant Cell Environ. 2006, 29, 315-330. [CrossRef]

60. Parry, M.A.; Reynolds, M.; Salvucci, M.E.; Raines, C.; Andralojc, P.J.; Zhu, X.G.; Price, G.D.; Condon, A.G.; Furbank, R.T. Raising yield potential of wheat. II. Increasing photosynthetic capacity and efficiency. J. Exp. Bot. 2011, 62, 453-467. [CrossRef]

61. Lin, M.T.; Occhialini, A.; Andralojc, P.J.; Devonshire, J.; Hines, K.M.; Parry, M.A.; Hanson, M.R. $\beta$-Carboxysomal proteins assemble into highly organized structures in Nicotiana chloroplasts. Plant $J$. Cell Mol. Biol. 2014, 79, 1-12. [CrossRef] [PubMed]

62. Kromdijk, J.; Głowacka, K.; Leonelli, L.; Gabilly, S.T.; Iwai, M.; Niyogi, K.K.; Long, S.P. Improving photosynthesis and crop productivity by accelerating recovery from photoprotection. Science 2016, 354, 857-861. [CrossRef] [PubMed]

63. Constabel, C.P.; Ryan, C.A. A survey of wound- and methyl jasmonate-induced leaf polyphenol oxidase in crop plants. Phytochemistry 1998, 47, 507-511. [CrossRef]

64. Winters, A.L.; Minchin, F.R.; Michaelson-Yeates, T.P.; Lee, M.R.; Morris, P. Latent and active polyphenol oxidase (PPO) in red clover (Trifolium pratense) and use of a low PPO mutant to study the role of PPO in proteolysis reduction. J. Agric. Food Chem. 2008, 56, 2817-2824. [CrossRef] [PubMed]

65. Becker, A. Virus-Induced Gene Silencing. Methods Mol. Biol. 2011, 236, 287-294.

66. Salim, V.; Yu, F.; Altarejos, J.; Luca, V.D. Virus-induced gene silencing identifies Catharanthus roseus 7-deoxyloganic acid-7-hydroxylase, a step in iridoid and monoterpene indole alkaloid biosynthesis. Plant J. 2013, 76, 754-765. [CrossRef] [PubMed]

67. Isaacson, T.; Damasceno, C.M.B.; Saravanan, R.S.; He, Y.; Catalá, C.; Saladié, M.; Rose, J.K. Sample extraction techniques for enhanced proteomic analysis of plant tissues. Nat. Protoc. 2006, 1, 769. [CrossRef] [PubMed]

68. Carvalho, P.C.; Fischer, J.S.G.; Xu, T.; Yates, J.R.; Barbosa, V.C. PatternLab: From mass spectra to label-free differential shotgun proteomics. Curr. Protoc. Bioinform. 2012, 13, 13-19.

69. Vizcaíno, J.A.; Csordas, A.; del-Toro, N.; Dianes, J.A.; Lavidas, I.; Mayer, G.; Perez-Riverol, Y.; Reisinger, F.; Ternent, T.; Xu, Q.W.; et al. 2016 update of the PRIDE database and related tools. Nucleic Acids Res. 2016, 44, D447-D456. [PubMed]

70. Usadel, B.; Nagel, A.; Thimm, O.; Redestig, H.; Blaesing, O.E.; Palacios-Rojas, N.; Selbig, J.; Hannemann, J.; Piques, M.C.; Steinhauser, D.; et al. Extension of the visualization tool MapMan to allow statistical analysis of arrays, display of corresponding genes, and comparison with known responses. Plant Physiol. 2005, 138, 1195-1204. [CrossRef]

71. Kanehisa, M.; Goto, S. KEGG: Kyoto Encyclopaedia of Genes and Genomes. Nucleic Acids Res. 2000, 28, 27-30. [CrossRef]

72. Hoon, M.J.L.D.; Imoto, S.; Nolan, J.; Miyano, S. Open source clustering software. Bioinformatics 2004, $20,1453$. [CrossRef] [PubMed] 
73. Larkin, M.A.; Blackshields, G.; Brown, N.P.; Chenna, R.; Mcgettigan, P.A.; Mcwilliam, H.; Valentin, F.; Wallace, I.M.; Wilm, A.; Lopez, R. Clustal W and Clustal X version 2.0. Bioinformatics 2007, 23, 2947-2948. [CrossRef] [PubMed]

74. Kumar, S.; Nei, M.; Dudley, J.; Tamura, K. MEGA: A biologist-centric software for evolutionary analysis of DNA and protein sequences. Brief. Bioinform. 2008, 9, 299-306. [CrossRef] [PubMed]

75. Bosch, M.; Berger, S.; Schaller, A.; Stintzi, A. Jasmonate-dependent induction of polyphenol oxidase activity in tomato foliage is important for defense against Spodoptera exiguabut not against Manduca sexta. BMC Plant Biol. 2014, 14, 257. [CrossRef] [PubMed]

(C) 2018 by the authors. Licensee MDPI, Basel, Switzerland. This article is an open access article distributed under the terms and conditions of the Creative Commons Attribution (CC BY) license (http:// creativecommons.org/licenses/by/4.0/). 